[RAdiocarbon, Vol. 14, No. 2, 1972, P. 418-451]

\title{
TRONDHEIM NATURAL RADIOCARBON MEASUREMENTS VI
}

\author{
REIDAR NYDAL, STEINAR GULLIKSEN, KNUT LÖVSETH
}

\author{
Radiological Dating Laboratory
}

The Norwegian Institute of Technology, Trondheim, Norway

\section{INTRODUCTION}

This date list covers most of the datings made during 1968 to 1970. Each sample is measured in one of the two counters described previously (R., 1970, v. 12, p. 205-237).

Counter 2, with an effective volume of $1.5 \mathrm{~L}$, has a present background and recent standard net count of 0.8 counts $/ \mathrm{min}$ and 18.8 counts $/ \mathrm{min}$, respectively. Counter 3 , with an effective volume of $1.1 \mathrm{~L}$ has a background of 2.4 counts/min and a recent standard net count of 14.2 counts/ min. The counters are operated at a $\mathrm{CO}_{2}$ pressure of 2 atmospheres.

Increasing demand for higher counting capacity on smaller amounts of sample material led to replacement of Counter 3 in 1971 by 2 new counters with cathode walls made from electrolytic copper plates supplied by AB Svenska Metallverken. They are both operated at 2 atmopheres $\mathrm{CO}_{2}$ pressure. One of these counters (Counter 5) has an effective volume of $0.9 \mathrm{~L}$, with background of 1.4 counts $/ \mathrm{min}$ and recent standard net count of 11.7 counts $/ \mathrm{min}$. The other counter (Counter 6) has an effective volume of $0.6 \mathrm{~L}$. Background and recent standard net count are 0.6 and 7.6 counts $/ \mathrm{min}$, respectively.

Realizing that the maintenance of our vacuum tube electronics would require increasing amounts of work and money, we designed new electronics by using integrated circuits. The prototype was operated in stability tests from the beginning of 1970. All our $\mathrm{C}^{14}$ units are now equipped with new electronics, and the results from the test period and the first 5 months of operation are very promising. The distribution of 65 individual counts on the background of Counter 6 gives $\sigma= \pm$ 0.028 counts $/ \mathrm{min}$ for each individual background count $(20 \mathrm{hr})$. Approximately the same standard deviation is obtained by assuming Poisson distribution within the individual counting periods.

Samples of wood, charcoal, and peat are generally treated with $1 \mathrm{M}$ HCl and $1 \mathrm{M} \mathrm{NaOH}$ to remove carbonates and humic acid. Treatment of peat with $\mathrm{NaOH}$ must be performed with caution, and is stopped before the solution of the peat has reached too far. The sample is placed in a glass filter and $300 \mathrm{ml}$ hot $\mathrm{NaOH}$ is added. Sample is then filtered within a few seconds with a pump. Shells are washed, dried, and surface treated with diluted $\mathrm{H}_{3} \mathrm{PO}_{4}$. Generally the weight of the shells is reduced 10 to $20^{\circ} \%$ by this treatment. In some cases an inner and an outer fraction of the same shells are dated separately to validate the surface treatment. Normally the difference in age for the two fractions is negligible; there are, however, exceptions where age differences are $>500$ yr for a sample ca. 10,000 yr old. 
Most samples were counted for $1200 \mathrm{~min}$, diluted samples $2400 \mathrm{~min}$. Alternating counting sample/background is applied for samples older than $30,000 \mathrm{yr}$, total counting time $10,000 \mathrm{~min}$. Background is counted weekly for $1200 \mathrm{~min}$, recent standard $2400 \mathrm{~min}$ each 2nd week.

All dates are calculated both in years before present (1950) and in the A.D./B.C. scale. The applied $\mathrm{C}^{14}$ half-life is $5570 \mathrm{yr}$; its standard deviation of $\pm 30 \mathrm{yr}$ is not included in the standard deviation $\left(\mathrm{I}_{\sigma}\right)$ of the dating results. We no longer find $\delta \mathrm{C}^{13}$ measurements of every sample very important, as corrections for fractionation error very seldom exceed 30 yr. $\delta \mathrm{C}^{13}$ measurements are performed mainly for scientific interest in studying geophysical problems. $\delta \mathrm{C}^{13}$ correction may be of some interest for very young samples, or for samples of doubtful origin. Relative to the PDB standard applied by Craig (1961), the normal $\mathrm{C}^{13}$ value in land vegetation is $-25 \%$, and the $\mathrm{C}^{14}$ activity in material from the land biosphere is corrected for isotopic fractionation to this value.

Shell samples from the Norwegian coast have $\delta \mathrm{C}^{13}$ values distributed around a mean value close to $0 \%$ relative to $\mathrm{PDB}$. In 1957, when dating was started, samples of recent shells with such $\delta \mathrm{C}^{13}$ values from the Trondheimsfjord were found to have $\mathrm{C}^{14}$ activity, corrected for age and contaminating effects, very close to $95 \%$ of the NBS oxalic standard. This result is now confirmed by the measurements on a series of 10 recent shell samples ( $\mathrm{T}-951$ to $\mathrm{T}-960$, this date list) from various parts of the Norwegian coast. Most shell samples are not anlyzed for $\delta \mathrm{C}^{13}$. When it is measured, the samples have been corrected to a $\delta \mathrm{C}^{13}$ value of $0 \%$. According to the observed correlation between recent shell activity and the oxalic acid standard, this method of calculation should give the true age of a shell sample.

Some other laboratories (e.g., Lund and Uppsala) are correcting shell samples to a $\delta \mathrm{C}^{13}$ value of $-25 \%$. The age of a shell sample, calculated by this method, is too great by a number of years corresponding to the apparent radiocarbon age of the sea water in which the shell originated. This has to be evaluated and subtracted to obtain the true age of the sample. Our opinion is that this method is of particular interest when recent shell activity is used in the study of geophysical problems. We feel however that submitters generally are more interested in having a probably true age for a sample than facing the circulation problems of the ocean water masses. Consequently we have decided to maintain our method of presenting shell dates.

\section{ACKNOWLEDGMENTS}

The authors wish to thank collectors and submitters of the samples for their collaboration in preparing the manuscript. $\mathrm{C}^{13} / \mathrm{C}^{12}$ ratios are measured by R. Ryhage, Karolinska Inst., Stockholm. Further thanks. to Elsa Riiser and Fred Skogseth for treating the samples. Financial support from Norges Almenvitenskapelige Forskningsråd is fully acknowledged. 


\section{SAMPLE DESCRIPTIONS}

I. GEOLOGIC SAMPLES

\section{A. Norway}

1. Interstadial and interglacial samples

\section{T-922. Skagerak moraine, Jaeren}

Marine shells at $+160 \mathrm{~m}$ from the Skagerak moraine at Opstad, Jaeren ( $58^{\circ} 40^{\prime} \mathrm{N}$ Lat, $5^{\circ} 42^{\prime} \mathrm{E}$ Long), Rogaland, Norway. Coll. by K. O. Björlykke; subm. 1970 by B. G. Andersen, Univ. Bergen. Comment (B.G.A.): only broken shells were found, and they are younger than the Skagerak moraine. They were deposited during a mid-Weichsel warm phase when Jaeren was deglaciated (Andersen, 1964).

T-923. Gann clay pit, Jaeren

Marine shells from Gann clay pit, at $+30 \mathrm{~m}$ at Sandnes, Jaeren (58 $48^{\prime} \mathrm{N}$ Lat, $5^{\circ} 45^{\prime} \mathrm{E}$ Long), Rogaland, Norway. From depth $8 \mathrm{~m}$ in glaciofluvial gravel, under- and overlain by clay with Yoldia. $1 \mathrm{~m}$ thick till covers the surface. Coll. 1968 and subm. 1970 by B. G. Andersen. Comment (B.G.A.): shells lived at Jaeren during a mid-Weichsel warm phase, and the upper part of the clay is younger than the shells.

T.921. Hauerseter m. 1-69

$40,000+3900$

Reindeer antlers from a sand pit with top surface at $+210 \mathrm{~m}$ in Hauerseter delta, $3.5 \mathrm{~km} \mathrm{~N}$ of Jessheim $\left(60^{\circ} 10^{\prime} \mathrm{N} \mathrm{Lat,} 11^{\circ} 10^{\prime} \mathrm{E} \mathrm{Long}\right)$, Akershus, Norway. Material in the $10 \mathrm{~m}$ deep sand pit is coarse grained on the top and finer towards bottom. Coll. 1966 by O. Kristiansen; subm. 1970 by S. R. Östmo, Univ. Oslo. Comment (S.R.ö.): sample was under avalanche material at the bottom of the sand pit and was thus supposedly either interglacial $(>30,000 \mathrm{yr})$ or same age as delta.

\section{Karmöy series, Hordaland}

Marine shells from Nygaard at $+11 \mathrm{~m}$ in Karmöy $\left(59^{\circ} 14^{\prime} \mathrm{N}\right.$ Lat, $5^{\circ} 15^{\prime} \mathrm{E}$ Long), Hordaland, Norway. Shell-bearing gravel (II) on rock surface lies below 5-m-thick marine sand and clay (I), strongly folded and till-like in upper part. Sample II from depth $5 \mathrm{~m}$, from shell-bearing gravel; Sample I from depth $4.5 \mathrm{~m}$, from sandy clay. Coll. by P. A. Öyen, Univ. Oslo; subm. 1969 by B. G. Andersen.

\section{T-796. Nygaardsprofilet I}

$39,000 \pm 2000$

T-797. Nygaardsprofilet II

$$
42,000 \pm 2000
$$

Comment (B.G.A.): dates agree well with dates from Jaeren and 
a date of shells from till near Nygaard. They indicate SW coast of Norway was deglaciated during mid-Weichsel (Öyen, 1905).

\section{Fjösanger series, Bergen}

Shell fragments and wood in para-autochthonous marine sediments from Fjösanger, Fana, Bergen $\left(60^{\circ} 21^{\prime} \mathrm{N}\right.$ Lat, $5^{\circ} 20^{\prime} \mathrm{E}$ Long), Hordaland, Norway. Sediments had been overridden by ice. Seal bones and a lump of gyttja were in sediments. Coll. and subm. 1968 by Jan Mangerud, Univ. Bergen.

\section{T-749. Fjösanger shell-fragments}

$$
46,000 \begin{gathered}
+5000 \\
-3000
\end{gathered}
$$

T-748. Fjösanger wood

Comment (J M): pollen analyses indicate sediments are intergacial (Mangerud, 1970a). Shell fragments were from different parts of sediment close to present surface. Date (T-749) is considered only minimum.

\section{Postglacial samples}

\section{T-1100. Ullevål Stadion}

$$
\begin{aligned}
& 8210 \pm 110 \\
& 6260 \text { B.C. }
\end{aligned}
$$

Wood, part of pine (Pinus silvestris) trunk, found below 2 to 2.5 $\mathrm{m}$ clay at $+98 \mathrm{~m}$ (i.e., present surface) near Ullevål Stadion, Oslo $\left(59^{\circ}\right.$ $57^{\prime} \mathrm{N}$ Lat, $10^{\circ} 44^{\prime} \mathrm{E}$ Long), Norway. Coll. 1948 and subm. 1971 by Anders Danielsen, Bot. Mus., Univ. Oslo, Norway. Comment (A.D.): soil samples from pine forest bottom enclosing trunk, gave almost exclusively pollen of Pinus, Betula, Corylus, Filices, strongly indicating Boreal age 8000 to 9000 B.P. (Hafsten, 1956, 1960). A land slide (Holtedahl, 1953) caused the pine forest to be buried under anaerobic conditions in clay at sea level.

\section{T-852. Vikedal II, Rogaland}

$8240 \pm 110$ 6290 B.C.

Gyttja from $2.5 \mathrm{~m}$ deep bog at $+85 \mathrm{~m}$ in Solheim, Vikedal $\left(59^{\circ}\right.$ $32^{\prime} \mathrm{N}$ Lat, $5^{\circ} 57^{\prime} \mathrm{E}$ Long), Rogaland, Norway. Coll. at depth $1.75 \mathrm{~m}$ in a drainage trench. Coll. and subm. 1969 by Karl Anundsen, Univ. Bergen. Comment (K.A.): bog rests on glacio-lacustrine silt and sand; glacial lake dammed by an ice-lake presumably in Younger Dryas time. Sediments are found up to $+130 \mathrm{~m}$, indicating that T-852 dates lake surface below $+85 \mathrm{~m}$, and not time for maximum extent.

\section{T-853. Vikedal III, Rogaland}

$8330 \pm 100$

6380 B.C.

Gyttja from base of $2.5 \mathrm{~m}$ deep bog at $+430 \mathrm{~m}$ between 2 great moraine ridges in Sötehei, Vikedal $\left(59^{\circ} 33^{\prime} \mathrm{N}\right.$ Lat, $6^{\circ} 03^{\prime} \mathrm{E}$ Long), Rogaland, Norway. Coll. with a Livingstone sampler. Sample coll. to date moraines, which correspond with Ra-moraines in Ryfylke (Andersen, 1954; 1960). Coll. and subm. by K. Anundsen. Comment (K.A.): T-853 seems too young. 


\section{Moraine series, Hordaland}

Gyttja from a bog, $4 \mathrm{~m}$ deep at $+56 \mathrm{~m}$ at Ryggjaheim Ungdomsherberge between Sandeid and ölen (59 $34^{\prime}$ N Lat, $5^{\circ} 49^{\prime}$ E Long), Hordaland, Norway. Bog underlain by clay. From base $0.05 \mathrm{~m}$ gyttja (Sample $\mathrm{I}$ is from the upper $0.03 \mathrm{~m}$ of this layer), $0.03 \mathrm{~m}$ clay, gyttja until the top. Coll. and subm. 1967 by K. Anundsen.

\section{T-663. Ryggjaheim I}

0.02 to $0.05 \mathrm{~m}$ above base.

\section{T-839. Ryggjaheim II}

0.08 to $0.13 \mathrm{~m}$ above base.

Comment (K.A.): T-663 and T-839 date clay horizon near base of bog. Clay is supposedly result of a climatic deterioration. T-663 and T-839 thus date this deterioration (in Pre-Boreal time). T-839 is presumably too young.

\section{T-585. Busnes, Kinsarvik}

Gyttja from base of $3 \mathrm{~m}$ deep bog, on a great flat at $+110 \mathrm{~m}$ in Busnes, Kinsarvik, Hardanger $\left(60^{\circ} 28^{\prime} \mathrm{N}\right.$ Lat, $5^{\circ} 56^{\prime} \mathrm{E}$ Long), Hordaland, Norway. Coll. and subm. 1966 by K. Anundsen. Comment (K.A.): T-585 dates a marine shore level, approx. corresponding with marine limit in a glacial front-delta in Eidfjord, further inland. T-585 thus gives approx. age of front-delta in Eidfjord.

\section{T-790. Ulvik 6, Hordaland}

$5980 \pm 90$

4030 B.c.

Pine wood from lake Instavatnet, Ulvik, Hardanger $\left(60^{\circ} 36^{\prime} \mathrm{N}\right.$ Lat, $7^{\circ} 00^{\prime} \mathrm{E}$ Long), Hordaland, Norway. From a pine $\log$ in bog ca. +700 $\mathrm{m}$, and 150 to $200 \mathrm{~m}$ above present pinewood limit. Coll. and subm. 1968 by Asbjörn Simonsen, Stavanger Mus., Stavanger. Comment (A.S.): date fully agrees with pollen diagrams from same area which show pinewood reached upper tree line during Atlantic period.

\section{T-791. Ulvik 7, Hordaland}

$9040 \pm 140$

7090 B.c.

Gyttja from bog, $0.86 \mathrm{~m}$ below surface, at $+950 \mathrm{~m}$ at lake Svartavatnet, Ulvik, Hardanger $\left(60^{\circ} 37^{\prime} \mathrm{N}\right.$ Lat, $7^{\circ} 00^{\prime} \mathrm{E}$ Long), Hordaland, Norway. Coll. and subm. 1968 by A. Simonsen. Comment (A.S.): dates upper part of "Eidfjord-Osa" cold spell of Pre-boreal age. This colder phase can be traced both in pollen diagram from lake Svartavatnet, and in glacial deposits (Anundsen and Simonsen, 1968).

\section{T-792. Ulvik 12, Hordaland}

$8720 \pm 130$

Peat from $0.84 \mathrm{~m}$ below surface in same bog as T-791. Coll. and subm. 1968 by A. Simonsen. Comment (A.S.): see T-791. 
Öyren series, Jaeren

Peat and gyttja from bog dammed up by a beach ridge close to shore at Öyren, Hå, Jaeren (58 $33^{\prime} \mathrm{N}$ Lat, $5^{\circ} 41^{\prime}$ E Long) Rogaland, Norway. Boat shed sites at $+1 \mathrm{~m}$ in bog (Simonsen, 1969). Coll. and subm. 1969 by A. Simonsen.

T-866. Öyren 1

A.D. 1310

$0.80 \mathrm{~m}$ below surface.

$640 \pm 60$

\section{T-867. Öyren 2}

$580 \pm 60$

$0.50 \mathrm{~m}$ below surface.

A.D. 1370

T-868. Öyren 3

$670 \pm 60$

$0.35 \mathrm{~m}$ below surface.

A.D. 1280

T-869. Öyren 4

$1190 \pm 60$

$0.15 \mathrm{~m}$ below surface. Comment (A.S.): T-866-T-868 date regrowth of former lagoon, once used as harbor. Dates indicate boat sheds must be medieval or older. T-869 supposedly contaminated by inactive carbon.

\section{T-752. Os, Hordaland}

$10,790 \pm 110$

Shell (Mya truncata, Saxicava pholas) from clayey till just above bed-rock surface in center (Osöyri) of Os $\left(60^{\circ} 11^{\prime} \mathrm{N}\right.$ Lat, $5^{\circ} 28^{\prime} \mathrm{E}$ Long), Hordaland, Norway. Coll. and subm. 1968 by Jan Mangerud, Univ. Bergen. Comment (J.M.): fabric of long axes of pebbles parallel to youngest glacial striae on rock surface beneath (Mangerud, 1970b).

\section{T-846. Eikangervåg, Hordaland}

\section{$11,930 \pm 140$} 9980 в.c.

Shell (Chlamys islandicus, Saxicava sp.) from fossil-bearing till, below till layer without fossils, at Eikangervåg, Lindås $\left(60^{\circ} 36^{\prime} \mathrm{N}\right.$ Lat, $5^{\circ} 24^{\prime}$ E Long), Hordaland, Norway. Coll. and subm. by J. Mangerud. Comment (J.M.): date indicates rapid retreat of ice during Alleröd Interstadial (Mangerud, 1970b).

\section{T-750. Sandviken, Bergen}

$12,470 \pm 150$

Shell (Chlamys islandicus) in clay below 2 beds of till in Sandviken, Bergen $\left(60^{\circ} 25^{\prime} \mathrm{N}\right.$ Lat, $5^{\circ} 20^{\prime} \mathrm{E}$ Long), Hordaland, Norway. Coll. and subm. 1968 by J. Mangerud. Comment (J.M.): date indicates Bergen area was ice free during Bölling Interstadial (Mangerud, 1970b).

\section{T.751. Grieghallen, Bergen}

$11,400 \pm 110$

Shell (Chlamys islandicus) in clay at Grieghallen, Bergen $\left(60^{\circ} 25^{\prime}\right.$ $\mathrm{N}$ Lat, $5^{\circ} 20^{\prime} \mathrm{E}$ Long), Hordaland, Norway. Coll. and subm. 1968 by 
J. Mangerud. Comment (J.M.): clay was consolidated by pressure of over-riding glacier. Stratigraphy not clear (Mangerud, 1970b).

\section{Aurlandsdalen series, Sogn og Fjordane}

Gyttja coll. with a $54 \mathrm{~mm}$ piston borer at various levels in $2.60 \mathrm{~m}$ deep bog at $+150 \mathrm{~m}$ in Loven, Aurlandsdalen $\left(60^{\circ} 53^{\prime} \mathrm{N}\right.$ Lat, $3^{\circ} 28^{\prime}$ E Long), Sogn og Fjordane, Norway. Coll. 1969 and subm. 1970 by Björn Bergström, Univ. Bergen.

T-985. Loven (BB54)

$7180 \pm 100$

1.25 to $1.28 \mathrm{~m}$ below surface. Comment (B.B.): dates rise of Pinus in pollen diagram.

T-986. Loven (BB54.9,1 and 9,2)

$9590 \pm 140$ 7640 в.c.

2.52 to $2.55 \mathrm{~m}$ below surface just above silt. Comment (B.B.): dates minimum $\mathrm{C}^{14}$ age of deglaciation in this part of Aurlandsdalen. Corresponds to high Betula and low Pinus values in pollen diagram (Bergström, 1971; Anundsen and Simonsen, 1968; Klovning and Hafsten, 1965).

\section{Torgarden series, Haramsöy}

Peat from Torgarden, Haramsöy $\left(62^{\circ} 40^{\prime} \mathrm{N}\right.$ Lat, $6^{\circ} 13^{\prime} \mathrm{E}$ Long), Möre og Romsdal, Norway. From $0.95 \mathrm{~m}$ thick peat at ca. +8 to 10 $\mathrm{m}$ between basal coarse sands and overlying (Tapes?) beach deposit 8 to $10 \mathrm{~m}$ high (known locally as "Remen"). Coll. and subm. 1969 by U. Hafsten, Univ. Trondheim. Comment (U.H.): macrofossil finds in or between dated layers suggest peat was formed near margin of a lagoon lake, which received inwash from adjacent dry land communities. After gradually becoming shallower, water appears to have had final deepening phase, related to rise in relative sea level and increased precipitation, with appearance of Phragmites in the swamp. Possible explanation for unrelated dates of T-827 II and T-830, may be penetration by Phragmites and Salix roots.

\section{T-827 I. Torgarden A}

$9480 \pm 150$

0 to $0.05 \mathrm{~m}$ above basal sand.

\section{T-827 II. Torgarden I}

$9640 \pm 120$ 7690 B.c.

0.15 to $0.20 \mathrm{~m}$ above basal sand. Pollen diagram (Pre-Boreal) shows high $(80 \%)$ Betula and start of Corylus curve, just above a Cyperaceae pollen maximum $(90 \%)$.

\section{T-828. Torgarden II}

$8920 \pm 110$

0.40 to $0.45 \mathrm{~m}$ above basal sand. Pollen diagram (Pre-Boreal) shows brief Betula minimum and corresponding maxima for Pinus and Salix, with a marked maximum $(80 \%)$ of health plants (mainly Empetrum). 


\section{T-829. Torgarden III}

$8340 \pm 140$ 6390 B.c.

0.65 to $0.70 \mathrm{~m}$ above basal sand. Pollen diagram (Pre-Boreal/Boreal) shows marked decrease in Betula and a corresponding increase in Pinus, with the lst low Corylus values, and increase in Cyperaceae pollen $(70 \%)$.

\section{T-830. Torgarden IV}

$8360 \pm 110$

0.75 to $0.80 \mathrm{~m}$ above basal sand. Pollen diagram (early Atlantic) shows beginning of Alnus curve and lies near Pinus maximum. Continued high values of Cyperaceae and increase in Salix.

\section{T-831. Torgarden $\mathbf{V}$}

0.90 to $0.95 \mathrm{~m}$ above basal sand. Pollen diagram (early Atlantic) shows rational Alnus limit $\left(\mathrm{A}_{\mathrm{o}}=10 \%\right)$, with continued high Alnus values $(50 \%)$ (Hafsten and Tallantire, ms. in preparation).

\section{Fuglemyra series, Trondheim}

Peat from various levels in bog profile at ca. $+160 \mathrm{~m}$ in Fuglemyra, Steinan, Trondheim (63 24' N Lat, $10^{\circ} 43^{\prime}$ E Long), Sör-Tröndelag, Norway. Coll. 1967; subm. 1970 by Ulf Hafsten and K. V. Knudsen, Univ. Trondheim.

\section{T-977. Steinan 1}

$\mathbf{7 4 0} \pm \mathbf{5 0}$

From depth $0.45 \mathrm{~m}$. Pollen analysis (K.V.K.): Sub-Atlantic. Comment (U.H.): dates rational Picea limit $\left(\mathrm{P}_{\mathrm{o}}\right)$.

\section{T.978. Steinan 2}

$1930 \pm 80$

From depth $0.75 \mathrm{~m}$. Pollen analysis (K.V.K.): early Sub-Atlantic. Comment (U.H.): dates start of agriculture in area (Cerealia-curve) and empirical Picea limit $\left(\mathbf{P}_{\mathrm{e}}\right)$.

\section{T-979. Steinan 3}

$3910 \pm 100$

From depth 1.25 m. Pollen analysis (K.V.K.): Sub-Boreal. Comment (U.H.): dates Corylus maximum just after main decline of Ulmus.

\section{T-980. Steinan 4}

$8270 \pm 70$

From depth $2.65 \mathrm{~m}$. Pollen analysis (K.V.K.): Boreal. Comment (U.H.): dates point at which the curves for Betula and Pinus intersect (rising Pinus).

\section{Koltjönn series, Nord-Tröndelag}

Samples coll. with a Hiller borer in lake Lille Koltjönn, at ca. $+159 \mathrm{~m}$ in Skage, Overhalla (64. $32^{\prime} \mathrm{N}$ Lat, $11^{\circ} 45^{\prime} \mathrm{E}$ Long), NordTröndelag, Norway. Coll. and subm. 1968 by B. Vorren, Univ. Trond- 
heim. Comment (B.V.): lake L. Koltjönn is just above marine limit, and series gives general vegetational development in bedrock area of middle Namdalen.

\section{T-726. L. Koltjönn I}

$8020 \pm 150$

Fine detritus-dy, 7.05 to $7.15 \mathrm{~m}$ below surface. Pollen analysis (B.V.): beginning of Atlantic period. Comment (B.V.): dates beginning of Alnus expansion of area. First part of Atlantic period in Namdalen is dominated by Alnus.

\section{T-727. L. Koltjönn II}

$5610 \pm 110$

Fine detritus-dy, 6.05 to $6.15 \mathrm{~m}$ below surface. Pollen analysis (B.V.): 2nd part of Atlantic period. Comment (B.V.): dates final fall of Alnus curve, just below maximum of Ulmus. Ulmus in bedrock area of Namdalen reaches maximum $7 \%$ of total three-pollen. Farther $\mathbf{E}$ in CambroSilurian area, Ulmus reaches ca. $20 \%$ of total three-pollen sum.

\section{T-728. L. Koltjönn III}

$4300 \pm 100$

Wood pieces, 3.90 to $4.00 \mathrm{~m}$ below surface. Pollen analysis (B.V.): beginning of Sub-Boreal period. Comment (B.V.): wood layer was ca. $0.20 \mathrm{~m}$ above a preliminary $5 \%$ Picea phase. This spruce is connected with climatic deterioration ca. 2500 B.c. Preliminary spruce occurrences before expansion are quite common in Namdalen area.

\section{Kirkemyra series, Nord-Tröndelag}

Sphagnum peat from peat bog near church of Skage, Overhalla (64 $27^{\prime} \mathrm{N}$ Lat, $11^{\circ} 45^{\prime} \mathrm{E}$ Long), Nord-Tröndelag, Norway. Bog, which is now drained and overgrown with pine, is ca. $3 \mathrm{~m}$ deep and at ca. +12 m. Coll. and subm. 1968 by B. Vorren.

\section{T-784. Kirkemyra I}

$1800 \pm 80$

Low humified Sphagnum peat 1.85 to $1.90 \mathrm{~m}$ below surface. Comment (B.V.): dates time of landnam phase in area. Skage/Hunn is one of oldest farm sites in middle Namdalen. Date fits very well with former archaeologic date of earliest Iron age settlements in Namdalen (Sandnes, 1965). Birch forest was cleared, and Graminae and Rumex rise rapidly. Soon after cereal and weed pollen appear. Just after clearing, Picea curve rises from 1 to 6 to $7 \%$.

\section{T-785. Kirkemyra II}

$$
920 \pm 80
$$

Sphagnum peat, 0.95 to $1.05 \mathrm{~m}$ below surface. Comment (B.V.): dates predominating cultivation phase. Picea curve reached $15 \%$, but rises rapidly later on.

\section{Åsmyra series, Nord-Tröndelag}

Peat from bog Åsmyra at ca. $+45 \mathrm{~m}$ in Skage, Overhalla $\left(64^{\circ} 27^{\prime}\right.$ 
$\mathrm{N}$ Lat, $11^{\circ} 46^{\prime}$ E Long), Nord-Tröndelag, Norway. Coll. and subm. 1970 by B. Vorren. Comment (B.V.): bog is ca. $2 \mathrm{~km} \mathrm{~N}$ of recent settlement in Skage area, and is now surrounded by spruce forest of high quality. Vegetation of this hill region is one of richest in Overhalla (Vorren, 1970; 1971).

\section{T.937. Åsmyra I}

$1700 \pm 80$

Brown-moss peat coll. by Hiller borer 1.50 to $1.55 \mathrm{~m}$ below surface and close above humus-colored clay, ca. $0.10 \mathrm{~m}$ thick. Comment (B.V.): dates clearing and settling in area, where no farms are now situated.

\section{T-938. Åsmyra II}

$1130 \pm 80$

Sphagnum peat coll. by Hiller borer 1.35 to $1.40 \mathrm{~m}$ below surface. Comment (B.V.): dates time when spruce curve exceeds $10 \%$. Picea replaces Betula which formerly dominated this hill area. Rise of Picea curve is very slow; most diagrams from Namdalen show rapid Picea rise.

\section{Lifjellet series, Nord-Tröndelag}

Sphagnum-Cyperaceae peat from $2.05 \mathrm{~m}$ deep topogenous bog, ca. $+400 \mathrm{~m}$ on Lifjellet, between Gosen and Sibirien, Nordli $\left(64^{\circ} 29^{\prime} \mathrm{N}\right.$ Lat, $13^{\circ} 08^{\prime}$ E Long), Nord-Tröndelag, Norway. Coll. and subm. 1970 by B. Vorren. Comment (B.V.): Lifjellet series is part of a pollen-analytic study of Picea immigration to Tröndelag and Nordland, middle Norway.

\section{T-973. Lifjellet I}

$2150 \pm 70$

Sphagnum-Cyperaceae peat from depth 0.53 to $0.56 \mathrm{~m}$ with a 4 in. iron tube. Peat consists of Cyperaceae-rootlets, treated with $5 \%$ $\mathrm{KOH}$ for $24 \mathrm{hr}$, then treated with $5 \% \mathrm{HNO}$, and sieved through a 1 $\mathrm{mm}$ sieve. Fine grained material in filtrate was dated. Pollen analysis (B.V.): early Sub-Atlantic. Comment (B.V.): dates expansion of Picea in area; Picea pollen curve exceeds $10 \%$. Maximum Picea in diagram is $30 \%$.

\section{T-974. Lifjellet II}

$7300 \pm 100$

Carex-Sphagnum peat coll. with Hiller borer at depth 1.62 to 1.68 m. Pollen analysis (B.V.): early Atlantic. Comment (B.V.): dates some preliminary Picea, reaching 2\%. Pinus curve descends from a Pinus phase, Betula and, soon after, Alnus curve ascends.

\section{Brennmoan series, Nord-Tröndelag}

Sphagnum-Cyperaceae peat from $0.75 \mathrm{~m}$ minerogenous bog, ca. +90 $\mathrm{m}$ in Brennmoan, Öysletta, Overhalla, (64. $29^{\prime} \mathrm{N}$ Lat, $12^{\circ} 05^{\prime} \mathrm{E}$ Long), Nord-Tröndelag, Norway. From $0.20 \times 0.20 \mathrm{~m}$ peat core. Coll. 1969 and subm. 1970 by $\mathrm{B}$. Vorren. Material for $\mathrm{C}^{14}$ is treated in the same way as Lifjellet I (T-973). Comment (B.V.): Brennmoan series is part of pollen-analytic study connected with historian "Ödegård" project of 
events about time of the Black Death. Bog is some meters below an ancient farm being excavated by Kr. Möllenhus, Videnskapsselskapets Oldsaksamling, Trondheim. Farm is ca. 1 to $2 \mathrm{~km} \mathrm{SE}$ of recent settlement of öysletta.

\section{T-975. Brennmoan I}

$$
530 \pm 60
$$

\section{A.D. 1420}

From depth 0.34 to $0.36 \mathrm{~m}$ below surface. Pollen analysis (B.V.): late Sub-Atlantic. Comment (B.V.): dates cessation of descending curves for barley, oats and weeds, just before sharp Picea expansion from 10 to $70 \%$. Farm was probably abandoned at time of Picea expansion.

\section{T-976. Brennmoan II}

$1420 \pm 80$

From depth 0.52 to $0.54 \mathrm{~m}$ below surface. Pollen analysis (B.V.): Sub-Atlantic. Comment (B.V.): dates settlement of farm.

\section{T-786. Ekle-Tiller I, Trondheim}

$10,230 \pm 130$ 8280 B.C.

Shells (Barnacles) from Ekle gravel pit at $+150 \mathrm{~m}$, Ekle, Trondheim (63 22' N Lat, $10^{\circ} 26^{\prime} \mathrm{E}$ Long), Sör-Tröndelag, Norway. From layer of sandy clay $25 \mathrm{~m}$ below marine limit and above an outwash delta. Coll. 1967 and subm. 1968 by Arne Reite, Norges Geol. Undersökelse, Trondheim. Comment (A.R.): indicates Ekle-Tiller outwash delta was deposited during Younger Dryas sub-stage (Holtedahl, 1928; Undås, 1934; Öyen, 1915).

\section{T-787. Ekle-Tiller II, Trondheim}

$$
\begin{gathered}
11,290 \pm 190 \\
9340 \text { B.c. }
\end{gathered}
$$

A whale vertebra from Tiller gravel pit, at $+150 \mathrm{~m}$ at Tiller, Trondheim (63 22' N Lat, $10^{\circ} 24^{\prime} \mathrm{E}$ Long), Sör-Tröndelag. From outwash delta at depth $15 \mathrm{~m}$. Age is older than, or simultaneous with outwash sediments ( $>9000 \mathrm{yr}$ ). Coll. 1962 by Karl Skjetne, Tiller; subm. 1968 by A. Reite. Comment (A.R.): indicates Trondheim area was ice free in Alleröd time.

\section{T-854. Ekle-Tiller III, Trondheim}

$10,150 \pm 100$ 8200 B.c.

Shells (Mya truncata) from Ekle gravel pit, at $+150 \mathrm{~m}$, Ekle, Trondheim (63 $22^{\prime} \mathrm{N}$ Lat, $10^{\circ} 26^{\prime} \mathrm{E}$ Long), Sör-Tröndelag, Norway. From marine clay at $25 \mathrm{~m}$ below marine limit and above outwash delta at Ekle-Tiller. Coll. and subm. 1969 by A. Reite. Comment (A.R.): indicates Ekle-Tiller outwash delta was deposited during Younger Dryas sub-stage. Barnacles from this locality were dated at 10,230 $\pm 130 \mathrm{yr}$ (T-786).

\section{T-756. Nordsand, Nordland}

$5520 \pm 110$ 3570 B.C.

Peat from base of $1.60 \mathrm{~m}$ thick bog profile in Nordsand, öksnes $\left(68^{\circ} 55^{\prime} \mathrm{N}\right.$ Lat, $14^{\circ} 55^{\prime}$ E Long), Nordland, Norway. Coll. and subm. 
1968 by Dagfinn Moe, Univ. Bergen. Comment (D.M.): dates beginning of ombrosoligenous bogs in Nordsand.

\section{T-757. Röstlandet, Nordland}

$860 \pm 70$ A.D. 1090

Sphagnum peat from base of regrown basin at 0.54 to $0.57 \mathrm{~m}$ depth on Röstlandet, Röst (67 $32^{\prime} \mathrm{N}$ Lat, $12^{\circ} 10^{\prime}$ E Long), Nordland, Norway. Coll. and subm. 1968 by D. Moe.

\section{T-927. N Hellöy, Nordland}

$1700 \pm 70$

Ericaceous peat coll. with a piston borer from basal layer of $0.90 \mathrm{~m}$

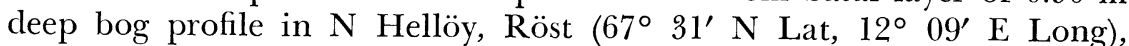
Nordland, Norway. Coll. 1969 and subm. 1970 by D. Moe. Comment (D.M.): date 1000 yr younger than expected.

\section{Slettbakkmyr series, Nordland}

Peat and wood from bog profile at $+29 \mathrm{~m}$ in Slettbakkmyr, Ramsvik, Vestvågöy $\left(68^{\circ} 07^{\prime} \mathrm{N}\right.$ Lat, $13^{\circ} 40^{\prime} \mathrm{E}$ Long), Nordland, Norway. Bog overlies stones and is $2.94 \mathrm{~m}$ thick at this section. Coll. and subm. 1968 by D. Moe.

\section{T-753. Slettbakk Peat}

$3060 \pm 90$

Depth below soil surface 0.66 to $0.68 \mathrm{~m}$.

\section{T-754. Slettbakk Birch}

$4740 \pm 110$

2790 B.C.

From strongly humified horizon. Depth below soil surface $1.15 \mathrm{~m}$.

\section{T-755. Slettbakk Peat (lowest layer)}

$8660 \pm 110$

Depth below soil surface 2.87 to $2.91 \mathrm{~m}$.

\section{B.C.}

\section{T-930. Slettbakk Peat (lowest layer)}

$9860 \pm 120$

Gyttja coll. with a piston borer at base of bog profile $2.90 \mathrm{~m}$ deep. Coll. 1969 and subm. 1970 by D. Moe. Comment (D.M.): T-755 and T-930 are from same layer, but T-755 material taken with Hiller sampler. T-930 is probably more reliable and dates oldest organic material from Slettbakk.

\section{T-963. Endletsvann 1, Andöya}

$12,710 \pm 200$ 10,760 в.c.

Gyttja from mire at ca. $+33 \mathrm{~m}, 200 \mathrm{~m}$ from small lake Endletsvann (+32 m), Andöya $\left(69^{\circ} 15^{\prime} \mathrm{N}\right.$ Lat, $16^{\circ} 05^{\prime} \mathrm{E}$ Long), Nordland, Norway. Coll. with Hiller borer at depth 7.42 to $7.52 \mathrm{~m}, 0.05 \mathrm{~m}$ above and below distinct transition from black (below) to brownish (above) gyttja. Coll. and subm. 1970 by K.-D. Vorren, Tromsö Mus., Tromsö. Comment (K.-D.V.): sub-fossils reveal arctic vegetation phase with Dryas communities in uppermost layers of black freshwater gyttja. 


\section{Deggemyra series, Troms}

Sphagnum peat from bog Deggemyra at ca. $+8 \mathrm{~m}$ near farm Hofsöy, Tranöy (69 $04^{\prime} \mathrm{N}$ Lat, $17^{\circ} 05^{\prime} \mathrm{E}$ Long), Troms, Norway. Coll. with a Hiller borer. Coll. and subm. by K.-D. Vorren. Comment (K.-D.V.): series is part of pollen-analytic study of settling and agricultural history in Troms and Vesterålen, N Norway. Deggemyra is close to ancient and abandoned farm (Simonsen, 1970, p. 113, fig.: "gravfelt").

\section{T-964. Hofsöy 1}

$$
1070 \pm 60
$$

From depth 0.42 to $0.50 \mathrm{~m}$.Pollen analysis: late Sub-Atlantic. Comment (K-D.V.): agricultural pollen shows marked final decline, just below dated strata. Because of a contemporary faint RY, this pollenanalytic event was linked with the Black Death (A.D. 1349). Date shows that assumption was incorrect. Decline of agricultural activity presumably originates from abandonment of farm.

\section{T-965. Hofsöy 2}

$$
1280 \pm 80
$$

From depth 0.85 to $0.90 \mathrm{~m}$. Pollen analysis (K.-D.V.): Sub-Atlantic (Viking age). Comment (K.-D.V.): date concerns culmination of most intensive cereal (Hordeum) cultivation phase at ancient farm.

\section{T-966. Hofsöy 3}

$1600 \pm 80$

From depth 1.25 to $1.30 \mathrm{~m}$. Pollen analysis (K.-D.V.): early SubAtlantic (Roman Iron age). Comment (K.-D.V.): date concerns time of settlement and clearing of ancient Norse farm, and fits well with archaeologic dates (Simonsen, 1970; Sjövold, 1962).

\section{Faerdesmyra series, Finnmark}

Peat from palsas in bog "Faerdesmyra" at $+70 \mathrm{~m}$ in Neiden, SörVaranger $\left(69^{\circ} 44^{\prime} \mathrm{N}\right.$ Lat, $29^{\circ} 19^{\prime}$ E Long), Öst-Finnmark, Norway. Coll. and subm. 1968-1970 by K. D. Vorren, Univ. Trondheim. Comment (K.-D.V.): dates from Faedesmyra concern genetic problems of palsas (Vorren, 1967), hummocks and $\mathrm{N}$ type of ombrotrophic bog sites (Ruuhijärvi, 1963).

\section{T-744. Pals M10, I}

$530 \pm 60$

Low-humified Sphagnum fuscum peat, 0.08 to $0.11 \mathrm{~m}$ below surface. Comment (K.-D.V.): dates maximum of formation of palsa.

\section{T-936. Pals M10, II}

Sphagnum lindbergii peat 0.21 to $0.23 \mathrm{~m}$ below surface from $2.5 \mathrm{~m}$ erosion wall. Comment (K.-D.V.): date concerns a distinct RY slightly above zone boundary Sub-Boreal/Sub-Atlantic. 
T-745. Pals M8, III

Low-humified Sphagnum lindbergii peat 0.01 to $0.03 \mathrm{~m}$ below winderoded surface. Comment (K.-D.V.): date was intended to give maximum age of formation of palsa in question, but is considered too old. The error is probably due to an unexpected strong peat erosion.

T-746. Hölje, IV

$4430 \pm 80$

2480 B.c.

Sphagnum lindbergii peat from 1.05 to $1.15 \mathrm{~m}$ below surface. Comment (K.-D.V.): date concerns an extended RY and transition from minerogenous to ombrogenous peat formation.

\section{T-910. Husfjord, Finnmark}

$9130 \pm 120$

Gyttja (fine detritus dy) from a topogenous bog at $+95 \mathrm{~m}$ in Husfjord, Hasvik, Söröya $\left(70^{\circ} 35^{\prime} \mathrm{N}\right.$ Lat, $22^{\circ} 55^{\prime} \mathrm{E}$ Long), Finnmark, Norway. Bog situated at edge of small lake near by distinct bottomendmoraines in Husfjord. Coll. with Hiller borer 1969 by K.-D. Vorren; subm. 1970 by U. Hafsten and K.-D. Vorren. Comment (K.-D.V.): date concerns time of deglaciation in area. Dated material is from lowermost strata.

\section{B. Finland}

\section{Peat bog series, N Finland}

Peat and gyttja from various bogs in $\mathrm{N}$ Finland (Lappalainen, 1970). Coll. 1963 to 1969 and subm. 1969 by E. Lappalainen, The Geological Survey, Otaniemi, Finland.

\section{T-821. Kairanaapa, No. 1}

$8410 \pm 100$

Peat from bog. Kairanaapa at $+155.1 \mathrm{~m}$ in Pelkosennieni $\left(67^{\circ}\right.$. $\mathrm{N}$ Lat, $27^{\circ} 3 \mathrm{I}^{\prime}$ E Long), N Finland. From depth 5.22 to $5.30 \mathrm{~m}$. Pollen analysis (E.L.): beginning of Boreal period. Previous date of $\log$ at same depth: $8430 \pm 160 \mathrm{yr}(\mathrm{I}-1912)$.

\section{T-823. Kairanaapa, No. 3}

$9170 \leq 150$ Path 6.40 to $6.48 \mathrm{~m}$ in same bog as T-821. Pollen analysis (E.L.): Picea 5\%, Pinus 10\%, Betula $85 \%$, from beginning of Pre-Boreal period.

\section{T-822. Liperi, No. 2}

$4340 \pm 80$

Wood (Populus) $29 \circ 30^{\prime} \mathrm{E}$ Lop), Littorina period, maximum $4000 \mathrm{yr}$.

T-824. Pahkavuoma, No. 4 
$25^{\circ} 00^{\prime}$ E Long), Finland. From depth 4.39 to $4.48 \mathrm{~m}$. Geologic dating (E.L.): ca. 6000 yr. Pollen analysis (E.L.): entrance of Alnus (ca. 5\%), Betula sharply decreases and Pinus increases. Sample belongs to end of Pre-Boreal period.

T-825. Parvavuoma, No. 5

$11,000 \pm 130$ 9050 B.c.

Peat (brown moss, Bryales) from bog Parvavuoma at $+179.6 \mathrm{~m}$ in Kittilä (67 $67^{\circ} \mathrm{N}$ Lat, $25^{\circ} 00^{\prime} \mathrm{E}$ Long), Finland. From depth 5.87 to $5.90 \mathrm{~m}$ at base of bog. Geologic date (E.L.): ca. 10,000 yr B.P. Comment (E.L.): previous date of same pollen-analytic horizon, $10,820 \pm 270 \mathrm{yr}$ B.P. (I-1666), in excellent agreement with present result. Sample belongs to Younger Dryas period.

T-826. Silmäsvuoma No. 6

$8660 \pm 130$

Gyttja from bog Silmäsvuoma at $+200.5 \mathrm{~m}$ in Kittilä $\left(67^{\circ} 33^{\prime} \mathrm{N}\right.$ Lat, $25^{\circ} 37^{\prime} \mathrm{E}$ Long), Finland. From depth 4.68 to $4.72 \mathrm{~m}$. Geologic date (E.L.): ca. 8000 yr. Pollen analysis (E.L.): Betula/Pinus shift at end of Pre-Boreal period.

\section{Markkina-aapa series, N Finland}

Samples from various levels in bog "Kakkupalsa" profile at +332.7 $\mathrm{m}$ in Markkina-aapa palsa area, Enontekiö $\left(68^{\circ} 30^{\prime} \mathrm{N}\right.$ Lat, $22^{\circ} 23^{\prime} \mathrm{E}$ Long), N Finland. Coll. 1968 and subm. 1969 by Martti Salmi, Inst. Quaternary Geol., Turku Univ.

T-801. Markina-aapa, 1/MS/69

$4150 \pm 50$

Peat (Carex-Bryales) coll. at depth 0 to $0.05 \mathrm{~m}$. Pollen analysis (M.S.): Pinus $55 \%$, Betula $43 \%$, Alnus $2 \%$ (2000 yr B.P.).

T-802. Markina-aapa, 2/MS /69

$7200 \pm 130$ 5250 B.c.

Peat (Carex-Bryales) coll. at depth 0.45 to $0.55 \mathrm{~m}$. Pollen analysis (M.S.): Pinus-maximum (5400 yr B.P.).

T-803. Markina-aapa, 3/MS/69

$7800 \pm 130$ 5850 B.C.

Peat (Carex-Bryales) coll. at depth 0.95 to $1.05 \mathrm{~m}$. Pollen analysis (M.S.): boundary between Betula and Pinus maximum (7800 yr B.P.).

\section{T-804. Markina-aapa, 4/MS/69}

$8460 \pm 140$

Gyttja (detritus) coll. at depth 1.60 to $1.70 \mathrm{~m}$ above mineral bottom. Pollen analysis (M.S.): Betula maximum (8800 yr B.P.).

\section{Kelottijänkä series A, N Finland}

Samples from various levels in bog profile at $+360.3 \mathrm{~m}$ in Kelottijänkä, Enontekiö $\left(68^{\circ} 34^{\prime} \mathrm{N}\right.$ Lat, $22^{\circ} 00^{\prime} \mathrm{E}$ Long), N Finland. Coll. 1968 and subm. 1969 by M. Salmi. 
T-805. Kelottijänkä, 5/MS/69

$1320 \pm 70$

Peat (Sphagnum) coll. at depth 0 to $0.05 \mathrm{~m}$. Pollen analysis (M.S.): Betula $68 \%$, Pinus $31 \%$, and Alnus 1\% (1000 yr в.P.).

\section{T-806. Kelottijänkä, 6/MS/69}

$8000 \pm 130$

Peat (Carex-Bryales) coll. at depth 2.35 to $2.45 \mathrm{~m}$. Pollen analysis (M.S.): boundary between Betula and Pinus maximum (7700 yr B.P.).

\section{T-807. Kelottijänkä, 7/MS/69}

$8690 \pm 100$

Peat (Carex-Sphagnum) coll. at depth 3.20 to $3.25 \mathrm{~m}$. Pollen analysis (M.S.): Betula maximum (8700 yr B.P.).

\section{Kelottijänkä series B, N Finland}

Samples from various levels in a bog profile at $+359.0 \mathrm{~m}$ in Kelottijänkä. Coll. 1967 and subm. 1969 by M. Salmi.

\section{T-808. Kelottijänkä, 8/MS/69}

$3520 \pm 80$

Peat (Sphagnum-Bryales) coll. at depth 0.18 to $0.23 \mathrm{~m}$. Pollen analysis (M.S.): from upper part of Pinus maximum and beginning of Picea curve (2500 yr B.P.).

T-809. Kelottijänkä, 9/MS/69

$5830 \pm 90$ 3880 в.c.

Peat (Sphagnum-Bryales) coll. at depth 0.57 to $0.63 \mathrm{~m}$ at contact between frozen and not frozen palsa. Pollen analysis (M.S.): upper part of Pinus maximum (5000 yr B.P.).

\section{T-810. Kelottijänkä, 10/MS/69}

$6920 \pm 110$ 4970 B.C.

Peat (Sphagnum-Bryales) from frozen palsa at depth 1.75 to 1.85 m. Pollen analysis (M.S.): lower part of Pinus maximum (7000 yr B.P.).

\section{T-811. Kelottijänkä, 11/MS/69}

$8190 \pm 140$

Peat (Bryales-Sphagnum) from frozen palsa at depth 2.58 to $2.68 \mathrm{~m}$. Pollen analysis (M.S.): boundary between Betula and Pinus maximum (7800 yr в.P.).

\section{Jurmunaapa series, $N$ Finland}

Samples from various levels in bog profile at $+235.8 \mathrm{~m}$ in Jurmunaapa, Sodankylä (68 $08^{\circ}$ N Lat, $26^{\circ} 46^{\prime}$ E Long), N Finland. Coll. 1960 and subm. 1969 by M. Salmi.

\section{T-812. Jurmunaapa, 12/MS/69}

$8110 \pm 110$

Peat (Bryales-Sphagnum) coll. at depth 3.05 to $3.15 \mathrm{~m}$. Pollen analysis (M.S.): boundary between Betula and Pinus maximum (7500 yr B.P.). 
T-813. Jurmunaapa, 13/MS/69

$8450 \pm 110$

Peat (Bryales-Sphagnum) coll. at depth 3.45 to $3.55 \mathrm{~m}$. Pollen analysis (M.S.): from upper part of Betula maximum (8500 yr B.P.).

\section{T-814. Silmäsvuoma, 14/MS/69}

$9000 \pm 140$

7050 в.c.

Bryales mud from bog profile at $+200.0 \mathrm{~m}$ in Silmäsvuoma, Kittilä (67 $25^{\prime} \mathrm{N}$ Lat, $25^{\circ} 30^{\prime} \mathrm{E}$ Long), N Finland. Coll. at depth 5.20 to $5.25 \mathrm{~m}$, from contact between silt and organogenic material. Coll. 1964 and subm. 1969 by M. Salmi. Pollen analysis (M.S.): upper part of Betula maximum (8500 yr B.P.).

\section{T-815. Hautavuoma, 15/MS/69}

$7790 \pm 110$ 5840 B.C.

Peat from bog profile at $+192.6 \mathrm{~m}$ in Hautavuoma, Kittilä $\left(67^{\circ}\right.$ $23^{\prime} \mathrm{N}$ Lat, $24^{\circ} 35^{\prime} \mathrm{E}$ Long), N Finland. Coll. at depth 3.55 to $3.60 \mathrm{~m}$ from contact between "siderit" (?) and Carex peat. Coll. 1964 and subm. 1969 by M. Salmi. Pollen analysis (M.S.): beginning of Pinus maximum (7800 yr B.P.).

\section{Canada}

\section{L'Anse aux Meadows series, Newfoundland}

Additional samples of peat and gyttja from turf walls, bogs, and tarns at or near Norse settlement site, L'Anse aux Meadows $\left(51^{\circ} 34^{\prime} \mathrm{N}\right.$ Lat, 55 $35^{\circ}$ W Long), Newfoundland (see H. Ingstad, 1964 and 1970; A. S. Ingstad, 1971; Nydal et al., 1970). Coll. 1968 and subm. 1969 to 1970 by Kari Henningsmoen, Univ. Oslo.

\section{T-816. "Mosquito bog"}

$5680 \pm 120$ 3730 в.C.

Gyttja from bog at ca. $+20 \mathrm{~m}, 8$ to $10 \mathrm{~km}$ from settlement site. Coll. with a Hiller borer at depth 3.40 to 3.50. Comment (K.H.): bog is inland. Surroundings are forest covered, uninhabited, and apparently undisturbed by man until quite recently. Pollen diagram from bog and date show a very monotonous vegetation development through last $5680 \mathrm{yr}$.

\section{T-817. Turf wall, House D}

$1300 \pm 70$

Sample from dark layer in ruin wall at depth 0.20 to $0.24 \mathrm{~m}$.

\section{T-818. Turf wall, House A}

$$
1320 \pm 80
$$

Sample from dark layers in ruin wall at depth 0.28 to $0.42 \mathrm{~m}$ below surface. Comment (K.H.): walls are built of turf layers, presumably taken from vegetation surface ca. A.D. 1000. Both dates seem reasonable from this point of view, see also Nydal et al., 1970 and A. S. Ingstad, 1971). 


\section{T-819. Tarn peat at dig area}

Peat coll. with a Hiller borer at depth 0.60 to $0.70 \mathrm{~m}$.

T-906. Tarn gyttja at dig area A.D. 660

Gyttja coll. with a Livingstone sampler at depth 1.02 to $1.07 \mathrm{~m}$. Comment (K.H.): Samples T-819 and T-906 confirm previous assumptions (Nydal et al., 1970) based on pollen diagram from tarn, that changes in vegetation are older than Norse settlement and must be ascribed to local ecologic development at sampling site.

\section{T-820. Palsa bog, Hiller sample}

$5320 \pm 60$ $1.73 \mathrm{~m}$. Comment 1.63 to (K.H.). ruins are situated on an old beach terrace +4 to $+6 \mathrm{~m}$. Date of bottom organic layers is minimum for time elapsed since this part of terrace was isolated from sea. Date agrees well with T-500 (Nydal et al., 1970), from basin somewhat lower on same terrace.

\section{T-905. Palsa bog, knife sample}

$460 \pm 80$

Peat from a trench wall at depth 0.30 to $0.35 \mathrm{~m}$. Comment (K.H.): plant remains from upper, unfrozen peat layers $(0$ to $0.35 \mathrm{~m})$ of bog were studied by K.-D. Vorren, who concludes that dated sample is older than palsa development in bog. Consequently, permafrost here is rather young and first developed well after Norsemen left site, presumably during cold spell of "Little Ice age".

\section{ARCHAEOLOGIC SAMPLES}

\section{Settlement sites}

\section{Laerdal series, Sogn og Fjordane}

Comment (A.B.J.): charcoal samples from artifact-bearing layers on some of numerous unstratified Stone-age settlements along Laerdal watercourse in Laerdal, Sogn og Fjordane. Artifacts are abundant on sites, but with strikingly few distinct tools. The traditional typologic method, therefore, is of less use than usual in dating settlements (Johansen, 1969). Results agree with our previous knowledge of early Post-glacial settlement in this area. First occupation took place very rapidly, perhaps not $>1000$ yr after ice retreat. This appears from several dates (see also R., 1970, v. 12, p. 205-237), especially from Sundet II (T-893), Sulemarki VII (T-671, T-900), Osen III (T-896), Jukleåni (T-667-T-669) and Osen II (T-664-T-666), all falling in the interval ca. 7000 to ca. 8200 yr B.P.

\section{Eldrevatn series, Laerdal}

Charcoal from settlement sites at lake Eldrevatn, $+1120 \mathrm{~m}\left(61^{\circ}\right.$ $01^{\prime} \mathrm{N}$ Lat, $8^{\circ} 07^{\prime} \mathrm{E}$ Long). 


\section{T-770. 32. Ulvehaugen I (W21 II)}

$$
1160 \pm 80
$$

From top of artifact-bearing layer $0.10 \mathrm{~m}$ deep. Coll. 1968 by E. Mikkelsen, Historical Mus., Univ. Bergen.

T-892. 1. Ulvehaugen III (M23 II)

$6070 \pm 520$

From artifact-bearing layer 0.10 to $0.15 \mathrm{~m}$ deep. Coll. 1966 by Signe Hvoslef, Historical Mus., Univ. Bergen.

T-766. 35. Ulvehaugen I (V15 III)

$7120 \pm 140$

From fireplace 0.20 to $0.40 \mathrm{~m}$ deep. Coll. 1968 by E. Mikkelsen.

\section{T-898. Ulvehaugen I (V16 III)}

$7460 \pm 80$

From fireplace $0.30 \mathrm{~m}$ deep covered by a large stone. Coll. 1968 by A. Zachariassen, Historical Mus., Univ. Bergen.

\section{T-897. 26. Glitreöyni II (E11)}

$5780 \pm 220$

From artifact-bearing layer 0.06 to $0.08 \mathrm{~m}$ deep. Coll. 1967 by $\mathrm{S}$. Hvoslef.

\section{T-890. 22. Glitreöyni II (C13)}

$6490 \pm 130$

From artifact-bearing layer with burnt flakes of quartzite 0.08 to 0.10 m deep. Coll. 1967 by S. Hvoslef.

\section{T-769. 20. Glitreöyni II (C13)}

$8510 \pm 110$

From spot of charcoal under artifact-bearing layer $0.10 \mathrm{~m}$ deep. Coll. 1967 by S. Hvoslef.

\section{T-771. 23. Glitreöynyi I (H14)}

$$
5930 \pm 90
$$

3980 B.C. Hvoslef.

From artifact-bearing layer 0.05 to $0.08 \mathrm{~m}$ deep. Coll. 1967 by $\mathrm{S}$.

\section{T-765. 29. Osen II (F17)}

From charcoal layer 0.03 to $0.04 \mathrm{~m}$ deep covering interior of small house site close to a Stone age site. Coll. 1968 by A. B. Johansen.

\section{T-896. 31. Osen III (K11 to K12}

$7480 \pm 120$

From artifact-bearing layer 0.04 to $0.08 \mathrm{~m}$ deep. Coll. 1968 by A. B. Johansen.

\section{Vassetvatn series, Laerdal}

Coll. at lake Vassetvatn at $+1100 \mathrm{~m}\left(61^{\circ} 03^{\prime} \mathrm{N}\right.$ Lat, $7^{\circ} 53^{\prime} \mathrm{E}$ Long $)$. Only one site discovered in area surrounding this lake despite extensive search. 


\section{T-894. Bringa I (S13 III)}

From artifact-bearing layer 0.15 to $0.20 \mathrm{~m}$ deep. Coll. 1969 by I. M. Holm-Olsen, Historical Mus., Univ. Bergen.

\section{T-895. 3. Bringa I (S13 III)}

From artifact-bearing layer 0.15 to $0.20 \mathrm{~m}$ deep. Coll. 1969 by I. M. Holm-Olsen.

\section{T-891. 36. Bringa I (R10)}

From artifact-bearing layer $0.30 \mathrm{~m}$ deep. Coll. 1968 by I. M. HolmOlsen. Comment (A.B.J.): site perhaps was used for only a restricted period. According to the tools found, this period is in the later part of the stone-using era. Dates, therefore, indicate stone was important as a tool material long after introduction of metals.

\section{Sulevatn series, Laerdal}

Coll. at lake Sulevatn at $+1420 \mathrm{~m}\left(61^{\circ} 05^{\prime} \mathrm{N}\right.$ Lat, $8^{\circ} 14^{\prime} \mathrm{E}$ Long $)$.

T-772. 38. Kyrkjenosi II (08)

$$
6020 \pm 110
$$

4070 в.c.

From spot of charcoal in artifact-bearing layer ca. $0.10 \mathrm{~m}$ deep. Coll. 1968 by K. Jansen, Historical Mus., Univ. Bergen.

\section{T-899. 37. Kyrkjenosi II (K9 II)}

$6070 \pm 130$

From artifact-bearing layer ca. $0.10 \mathrm{~m}$ deep. Coll. by K. Jansen.

\section{T-900. 13. Sulemarki VII (K14)}

$7630 \pm 450$

From spot of charcoal $0.10 \mathrm{~m}$ deep. A sample from deeper layer 2 to $3 \mathrm{~m}$ away is dated to $7920 \pm 120$ yr (T-671: R., 1970, v. 12, p. 228). Coll. 1967 by S. Indrelid, Historical Mus., Univ. Bergen.

\section{Store öljusjö series, Laerdal} Long).

Coll. at lake Store öljusjö at $+1310 \mathrm{~m}\left(60^{\circ} 58^{\prime} \mathrm{N}\right.$ Lat, $8^{\circ} 04^{\prime} \mathrm{E}$

\section{T-893. 31. Sundet II (E6)}

$7670 \pm 150$

From bottom of wall mound in house site 0.50 to $0.60 \mathrm{~m}$ deep. Coll. by A. B. Johansen. Comment (A.B.J.): result agrees with results of statistical analysis of non-tool artifact material (Johansen, 1969).

\section{T-767. 28. Kjölåni $V$ (08)}

$970 \pm 70$

From below wall of house site. Coll. 1967 by O. M. Osaland, Historical Mus., Univ. of Bergen. Comment (A.B.J.): result may indicate hunting or fishing in this area in viking period, but no bones were found. 


\section{T-768. Kalvsundet, $N$ Hordaland}

$1050 \pm 70$

A.D. 900

Charcoal from depth $0.20 \mathrm{~m}$ in a charcoal kiln at Kalvsundet, Lygra, Lindås $\left(60^{\circ} 40^{\prime} \mathrm{N}\right.$ Lat, $5^{\circ} 07^{\prime} \mathrm{E}$ Long), N Hordaland, Norway. Coll. and subm. 1968 by A. B. Johansen. Comment (A.B.J.): kiln is 1 of ca. 40 similar remains in a restricted area.

\section{T-848. Bergsmulvatn II, Ustevassdraget}

$1800 \pm 70$

Charcoal from $0.05 \mathrm{~m}$ thick concentration at $+990 \mathrm{~m}$, Ustevassdraget, Hol $\left(60^{\circ} 30^{\prime} \mathrm{N}\right.$ Lat, $7^{\circ} 40^{\prime} \mathrm{E}$ Long), Buskerud, Norway. Coll. 1960 by Nils Lien; subm. 1969 by Irmelin Martens, De arkeol. mus. registreringstjeneste, Oslo. Comment (I.M.): site is middle Neolithic, with stray finds of stone implements of a later date. There were also remains of a stone hut probably 200 to $300 \mathrm{yr}$ old. Sample from opposite part of site, where chances for mixture with late elements should be least.

\section{T-849. Hovatn III, Finndalen}

$7240 \pm 100$

5290 в.C.

Charcoal from peat bog layer at $+690 \mathrm{~m}$ in site at Hovatn, Valle $\left(59^{\circ} 10^{\prime} \mathrm{N}\right.$ Lat, $7^{\circ} 40^{\prime} \mathrm{E}$ Long), Aust-Agder, Norway. Coll. 1960 by A. E. Christensen; subm. 1969 by I. Martens. Comment (I.M.): sample from periphery of a Stone age site with no clear connection between find layer and charcoal-containing layer in peat bog. Flint material dates from middle Neolithic period, and shows no sign of mixture with Mesolithic elements.

\section{T-850. Kjaerringnes, Ståvatn}

$4410 \pm 140$

2460 в.c.

Charcoal from Stone age site at $+970 \mathrm{~m}$ at Kjaerringnes, Ståvatn, Vinje ( $59^{\circ} 50^{\prime} \mathrm{N}$ Lat, $7^{\circ} 10^{\prime} \mathrm{E}$ Long), Telemark, Norway. From lowest part of 0.10 to $0.15 \mathrm{~m}$ thick sand layer below peat. Coll. 1960 by Gro Mandt; subm. 1969 by I. Martens. Comment (I.M.): sample derives from a Stone age site where rock crystal is the dominant raw material. Implements from this material cannot be dated exactly. Besides, also present are some clearly Neolithic flint implements, preferably middle Neolithic (ca. 2000 в.c.). Site was probably in use only during a shorter period, but as stratigraphy is lacking, this is uncertain. The use of rock crystal might very well be a Mesolithic tradition. Another site with similar inventory was dated to 4300 B.c. (T-260: R., 1964, v. 6, p. 289).

\section{T-851. Grössae, Bygland}

$5500 \pm 90$

3550 B.C.

Charcoal from a Stone age site, $+720 \mathrm{~m}$, at the river Grössae, Bygland $\left(59^{\circ} 0^{\prime} \mathrm{N}\right.$ Lat, $7^{\circ} 50^{\prime} \mathrm{E}$ Long), Aust-Agder, Norway. From depth 0.05 to $0.15 \mathrm{~m}$. Coll. 1968 by Agnete Rognes; subm. 1969 by I. Martens. Comment (I.M.): site has not been properly excavated; sample was coll. during a test dig of $1 \mathrm{~m}^{2}$. Main part of material consists of flint and is of middle Neolithic character, with some quartzite which 
might derive from a Mesolithic settlement phase, causing the early dating.

\section{Bone series, Vestfold}

Animal bones from cultural layer at depth 0.25 to $0.35 \mathrm{~m}$ in Frebergsvik, Borre (59 26 $\mathrm{N}$ Lat, $10^{\circ} 24^{\prime} \mathrm{E}$ Long), Vestfold, Norway. Artifacts were also found. Layer 1 of 5 digging layers down to depth $0.60 \mathrm{~m}$. Coll. 1969 and subm. 1970 by E. Mikkelsen, Univ. Oldsaksamling, Oslo.

T.928. Bone, G18III

\section{T-929. Bone, H18III}

Comment (E.M.): artifacts belong to settlement traditionally referred to as Nöstvedt culture. Archaeologic date and shoreline date indicate a time ca. 4000 в.c. There seems to be no important qualitative (or time) differences between artifacts in different layers.

\section{T-970. Frebergsvik IV, Vestfold}

$3850 \pm 110$

Charcoal from $+53 \mathrm{~m}$ in Frebergsvik, Borre $\left(59^{\circ} 26^{\prime} \mathrm{N}\right.$ Lat, $10^{\circ} 24^{\prime}$ E Long), Vestfold, Norway. From depth 0.23 to $0.25 \mathrm{~m}$. Coll. and subm. 1970 by E. Mikkelsen. Archaeologic date: older Stone age. Comment (E.M.): sample comes from same Stone age settlement as T-928 and T-929. It must belong to a later visit in Neolithic period at same place.

\section{Boathouse series II, Rogaland}

Charcoal from boathouses at Nord-Kolnes, Sola $\left(58^{\circ} 55^{\prime} \mathrm{N}\right.$ Lat, $5^{\circ} 08^{\prime}$ W Oslo), Rogaland, Norway. Coll. 1965 by Perry Rolfsen; subm. 1968 by O. Möllerop, Stavanger Mus., Stavanger. Comment (O.M.): this series is a supplement to previous one (R., 1970, v. 12, p. 233). More detailed analysis of material proved there was an older habitation on the spot. (Habitation layers under the walls with pottery of premigration period types). It is probable that the pottery below the $\mathbf{E}$ long wall (T-783) belongs to that habitation phase (Rolfsen, 1966).

T-781. Site 1, H 9

$1930 \pm 70$

From charcoal pit in middle of site, probably from wooden wall. Archaeologic date: A.D. 0 to 400 .

\section{T-782. Site 1, P 19}

$1820 \pm 70$

From middle of site in stratigraphically younger layer than T-783 (S 18). Archaeologic date: A.D. 200 to 400.

\section{T-783. Site 2, S 18}

$1830 \pm 70$

From below $\mathrm{E}$ long wall in site, and from same place as T-620 (R., 1970, v. 12, p. 233). Archaeologic date: A.D. 200 to 400. 


\section{T-780. Skagen 3 (No. 8), Stavanger}

$$
660 \pm 60
$$

Burnt grain from floor of old house from town of Stavanger $\left(58^{\circ}\right.$ $58^{\prime} \mathrm{N}$ Lat, $4^{\circ} 59^{\prime} \mathrm{W}$ Oslo), Rogaland, Norway. Coll. and subm. 1968 by O. Möllerop. Comment (O.M.): part of medieval house, wooden floor, and parts of roof and walls preserved, with many finds in and around house (organic material, pottery, runic inscriptions, etc.). Pottery sherds date habitation to 12th to 13th centuries and later (Lillehammer, 1969; Simonsen, 1969; Möllerop, 1969).

\section{House site, Rogaland}

Charcoal from house site with area of $42 \times 7.5 \mathrm{~m}$ in Espeland, Sandnes (58 $41^{\prime}$ N Lat, $5^{\circ} 48^{\prime} \mathrm{E}$ Long), Rogaland, Norway. Coll. 1966 by O. Espedal; subm. 1968 by O. Möllerop. Comment (O.M.): mostly pottery sherds from different parts. According to pottery, site was inhabited 5th and 6th centuries A.D. (Espedal, 1966; 1967).

\section{T-778. Espeland (G 17/19)}

$1540 \pm 70$

Sample from wood construction.

\section{T-779. Espeland (K 16/17 Pit II)}

Sample from firepit in central part of site.

$$
1690 \pm 70
$$

A.D. 540

\section{Stokkaland series, Rogaland}

Charcoal from settlement in Slettabö, Stokkaland, Ogna $\left(58^{\circ} 31^{\prime}\right.$ N Lat, $4^{\circ} 55^{\prime}$ E Long), Rogaland, Norway. Coll. and subm. 1966 to 1968 by Arne Skjölsvold, Univ. Oldsaksamling, Oslo. Comment (A.S.): 4 cultural layers were found in site; they reflect different settlement phases from Stone and Bronze age. The 3 uppermost layers which are dated here, are separated from each other with sterile sand and are stratigraphically well defined.

\section{T-629. Stokkaland VIII ( 1 i)}

$2840 \pm 130$

From 1st (youngest) cultural layer, at depth 0.55 to $0.60 \mathrm{~m}$ below soil surface.

T-740. Stokkaland III (2-0)

$2420 \pm 90$

From lst cultural layer at depth 0.57 to $0.59 \mathrm{~m}$. 470 B.C.

\section{T-626. Stokkaland V ( 5 1)}

From 1st cultural layer at depth 0.75 to $0.80 \mathrm{~m}$. 


\section{T-628. Stokkaland VII ( 3 1)}

$3860 \pm 100$

From 2nd cultural layer at depth 1.00 to $1.10 \mathrm{~m}$.

\section{T-739. Stokkaland II ( 5 n $)$}

1910 B.c.

From 2nd cultural layer at depth 1.10 to $1.20 \mathrm{~m}$.

$3790 \pm 70$

1840 B.C.

T-738. Stokkaland I ( $4, \mathrm{q})$

$4730 \pm 100$

2780 B.C.

From 3rd cultural layer at depth 1.50 to $1.60 \mathrm{~m}$.

\section{Rock shelter series, Möre og Romsdal}

Charcoal from firepits in rock shelter Dalehelleren, Kristiansund (63 $08^{\prime} \mathrm{N}$ Lat, $7^{\circ} 45^{\prime}$ E Long), Möre og Romsdal, Norway. Samples from 2 charcoal concentrations in lower part of cultural layer. Coll. 1969 by student Kurt Alterskjaer; subm. 1969 by Kr. R. Möllenhus, Videnskapsselskapets Oldsaksamling, Trondheim. Flint and bone artifacts were found.

\section{T-879. Dalehelleren I}

$$
\begin{aligned}
& 3040 \pm 70 \\
& 1090 \text { в.c. }
\end{aligned}
$$

\section{T-880. Dalehelleren II}

$2390 \pm 70$

Comment ( $\mathrm{Kr} \mathrm{R} \mathrm{M}$ ): dates indicate dwelling place was in for a long time, or, at 2 different times. The artifacts found are hardly dateable.

\section{Various archaeologic samples}

\section{Soapstone series, Kvikne}

Wood from soapstone quarry $\mathrm{W}$ of Bubakk, Kvikne $\left(62^{\circ} 25^{\prime} \mathrm{N}\right.$ Lat, $10^{\circ} 15^{\prime}$ E Long), Hedmark, Norway. Samples from depths between 1 and $3 \mathrm{~m}$ among ground and soapstone debris. Coll. and subm. 1968 to 1969 by Arne Skjölsvold. Sample from same quarry was dated earlier (2350 \pm 90 yrs: R., 1970, v. 12, p. 235).

\section{T-741. Bubakk I, 1968}

$2180 \pm 90$

Piece of wooden spade from depth $3 \mathrm{~m}$.

T-742. Bubakk II, 1968

230 B.C.

Birch bark from trunk, depth 3 in

$$
2440 \pm 70
$$

490 B.C. possibly used as framework against slides of earth and (A.S.): trunk was

\section{T-788. Bubakk I, 1969}

$2270 \pm 70$

Birch bark from a worked birch trunk, depth $3 \mathrm{~m}$.

T-789. Bubakk II, 1969

Piece of wooden spade from depth 2 to $2.5 \mathrm{~m}$. 
T-758. Wooden trackway, Tiltereidet, Romsdal

$1470 \pm 70$

Wood from trackway on isthmus Tiltereidet between Eidsöra and Eidsvåg, Toven, Nesset (62 $50^{\prime} \mathrm{N}$ Lat, $8^{\circ} 10^{\prime} \mathrm{E}$ Long), Romsdal, Norway. Trackway consists of $3 \mathrm{~m}$ stringers across and resting normally on 3 longitudinal sleepers, discovered in 1932 (Ording, 1935). Pollen-analytic date by Asbjörn Ording: early Middle age.

\section{Arrow shaft series, Oppdal}

Wooden arrow shafts lost by hunters through the ages; preserved in glaciers at +1500 to $1800 \mathrm{~m}$ in the Oppdal Mts., Sör-Tröndelag. Coll. by different persons at different times; subm. 1968 by O. Farbregd, Videnskapsselskapets Mus., Trondheim.

\section{T-774. Brattfonna}

$650 \pm 60$

Shaft of longbow arrow (Mus. no. T. 16055), (62 $22^{\circ} \mathrm{N}$ Lat, $9^{\circ}$ $45^{\prime}$ E Long), Norway. Comment (O.F.): typologically of youngest arrow shaft type found in area.

\section{T-775. Leirtjörnkollen}

$390 \pm 50$

Shaft of crossbow arrow, with iron head of triangular type (Mus. no. T. 17697 b), (62 $27^{\prime} \mathrm{N}$ Lat, $9^{\circ} 45^{\prime} \mathrm{E}$ Long), Norway.

\section{T-944. Klåstad ship, Tjölling}

$1150 \pm 80$

Piece of wood (Hazel ? twig from brushwood dunnage) from Viking age wreck excavated 1970 at Klåstad, Tjölling $\left(59^{\circ} 06^{\prime} \mathrm{N}\right.$ Lat, $10^{\circ} 10^{\prime}$ E Long), Norway. Coll. and subm. 1970 by A. E. Christensen Jr., Univ. Oldsaksamling, Oslo. Comment (A.E.C.): fragmentary ship seems to be wreck of a merchant vessel; some 50 unfinished whetstones were found, probably part of cargo. Construction of ship indicates date to 9 th or 10 th centuries.

\section{Cemetery series, Oppdal}

Charcoal from cremation layers and charcoal pits in large cemeteries

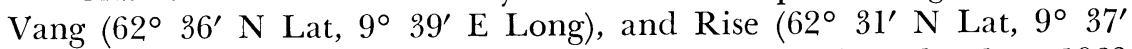
E Long), Sör-Tröndelag, Norway. Coll. 1966 to 1967 and subm. 1968 to 1969 by O. Farbregd.

\section{T-777. Vang, Barrow 560}

$$
1140 \pm 70
$$

From charcoal layer ca. $0.15 \mathrm{~m}$ below flat surface at edge of barrow. Assoc. artifacts: knife, bridle bit, an iron plate, pieces of whetstone (Mus. no. 18818 f). Comment (O.F.): this is probably not a grave. Stratigraphically, this separate deposit seems to be either contemporary with, or younger than central grave, archaeologically dated between A.D. 750 and 850 . 
T-843. Vang, Barrow 17

From charcoal layer below turf at edge of barrow (Mus. no. T.18754 $\mathrm{m})$. Comment (O.F.): obviously a secondary deposit, containing 3 bronze weights and some ashes. Probably not a grave.

\section{T-844. Vang, Barrow 17}

$1510 \pm 70$

Coll. in a charcoal concentration in subsoil near center of robbed barrow (Mus. no. $18754 \mathrm{~m}$ ). Comment (O.F.): assumed date of destroyed central grave, based on a few simple artifacts left: late Iron age: 7 th century?

\section{T-845. Vang, Barrow 211}

$1670 \pm 70$

Coll. in a charcoal pit dug $0.2 \mathrm{~m}$ down into subsoil below robbed barrow containing traces of burial from A.D. 600 to 900 (Mus. no. T.18756 q). Comment (O.F.): dates T-844 and T-845 may indicate cemetery was in use before A.D. 600, but it is not certain. Nature of these pits is not fully understood.

\section{T-776. Rise, Barrow 14}

$1230 \pm 70$

From charcoal concentration at base of perimeter trench, contemporary with building of barrow. Artifacts from ca. A.D. 400 to 800 found in partly levelled barrow (Mus. no. T.18822 z).

\section{T-840. Rise, Barrow 14}

$$
1430 \pm 70
$$

From cremation pit with a few metal fragments and a strike-a-light. Pit was dug ca. $0.3 \mathrm{~m}$ down into subsoil below barrow (Mus. no. T.18822 ae). Comment (O.F.): dates T-776 and T-840 indicate primary pit grave below flat surface, incidentally covered by a secondary barrow burial.

\section{T-841. Rise, Stone D}

$$
1130 \pm 60
$$

A.D. 830

From fire pit grave below flat surface, but covered by a small boulder. Artifacts: some metal fragments and a few glass beads (Mus. no. T.18826 g). Comment (O.F.): a grave monument without known local parallels.

\section{T-842. Rise, Barrow 27}

$$
\begin{aligned}
& 1280 \pm 60 \\
& \text { A.D. } 670
\end{aligned}
$$

From cremation layer under a barrow ca. $0.3 \mathrm{~m}$ high. Among grave furnishings, a small disc-shaped brooch common in Gotland in 7 th century, but rare in Norway (Mus. no. T.18825 e).

\section{Sund skeleton series}

A dozen skeletons (of mixed sexes and ages) interred in moraine gravel at Sund, (63 52' N Lat, $11^{\circ} 20^{\prime}$ E Long), Nord-Tröndelag, Norway, (Mus. no. T.18863). Some 8 skeletons in disorderly heap, others a 
few $m$ apart. Surrounding them all a circular trench, indicating perimeter of a removed cairn of barrow, some $12 \mathrm{~m}$ wide. Inside trench was also a charcoal pit, presumably part of burial complex. A single artifact found with skeletons: a simple bone pin. Excavated 1968 by $\mathrm{O}$. Farbregd; subm. 1968 and 1969 by K. R. Möllenhus and O. Farbregd.

T-747. Sund I

$3300 \pm 100$
1350 B.C.

Sample from a cranium in main concentration of skeletons.

$2900 \pm 90$

T-881. Sund II

950 B.C.

Sample from a femur of skeleton placed apart from others.

\section{T-925. Sund III}

$2950 \pm 90$

Charcoal from charcoal pit.

\section{Cemetery series, Etne, Hordaland}

Wood and charcoal from burial field at edge of river terrace at $+50 \mathrm{~m}$ in Sörheim, Etne $\left(59^{\circ} 35^{\prime} \mathrm{N}\right.$ Lat, $6^{\circ} 0^{\prime} \mathrm{E}$ Long), Hordaland, Norway. Coll. and subm. 1969 by Björn Myhre, Historical Mus., Univ. Bergen. Comment (B.M.): 10 barrows were lying in a row with flat graves between some of them. Biggest one must be dated to older Bronze age (1500 to 900 B.C.) and had also been used as burial place in migration period (A.D. 400 to 600). Rest of the cemetery consisted of small cairns difficult to see above ground, containing poor burnt graves with few objects, which must be dated to younger Iron age, probably Viking period (A.D. 800 to 1000). These poor graves seem to be usual burial costume in SW Norway in Viking period.

\section{T-858. Garahaugen I, Sörheim, Etne}

$3330 \pm 80$

From burial chamber in large mound Garahaugen. Comment (B.M.): burial chamber was robbed in 1904 and dagger of bronze (Stavanger Mus. S 2849) seems to have belonged to this chamber. Dagger archaeologically dated to older Bronze age-Period III (1100 to 900 B.c.). Body had been cremated; this is one of oldest cremation graves from Norway.

T-859. Garahaugen II, Sörheim, Etne

Iron grave at edge of Garahaugen, untouched since burial. Comment (B.M.): grave was only a layer of charcoal with some burnt bones. Poor cremation graves like this could archaeologically be dated to younger Bronze age (A.D. 900 to 500).

T-860. Garahaugen III, Sörheim, Etne

$3080 \pm 80$

Coll. from pit in ground below Garahaugen. Comment (B.M.): pit 
was dug into original ground and must be older than grave. Pit contained charcoal and burnt stones; it was probably cooking pit.

\section{T-861. Burial mound, Sörheim, Etne}

$1570 \pm 90$

Fragments from wooden pole in ground below burial mound. Com ment (B.M.): a small cairn ca. $10 \mathrm{~m}$ diam. and $0.75 \mathrm{~m}$ high contained a robbed grave with an axe, a bead, and some iron fragments. Grave can be dated to Viking period. Underneath barrow were found 6 post holes which could be assoc. with barrow. Date means perhaps that post holes are older than grave.

\section{T-962. Stone ring, Etne}

$2270 \pm 50$

Charcoal from earlier untouched fire grave in a stone ring. In the middle of a ring of 7 stones was a grave pit containing charcoal and burnt bones. This is the only grave of this type excavated in W Norway. Dates of similar graves in E Norway and Sweden are from 100 B.c. to A.D. 400 , but some Swedish ones are as old as this ring.

\section{T-972. Spranget (No. II), Rondane}

Charcoal from ash and charcoal layer at base of burial mound at $+1000 \mathrm{~m}$ at "Spranget", Mysuseter, Rondane $\left(61^{\circ} 50^{\prime} \mathrm{N}\right.$ Lat, $9^{\circ} 45^{\prime}$ E Long), Hedmark, Norway. Coll. and subm. 1970 by A. Skjölsvold, Archaeologic date: Iron age. Comment (A.S.): only specimen found was iron knife of a type which does not permit a closer date within Iron age.

\section{Burial mound series, östfold}

Charcoal from great mound Jellhaug in Jellestad, Berg, $\left(59^{\circ} 09^{\prime}\right.$ $\mathrm{N}$ Lat, $11^{\circ} 15^{\prime} \mathrm{E}$ Long), Östfold, Norway. Sample I was between fragments of burnt bones in trench dug through mound. Sample II from well-defined layer, possibly original surface of mound where vegetation was burnt before robbery of mound. Coll. and subm. 1969 by Erling Johansen, Univ. Oldsaksamling, Oslo.

\section{T-887. Jellhaug I}

$$
1540 \pm 90
$$

\section{T-888. Jellhaug II}

$1200 \pm 80$

Comment (E.J.): dates are not contradicted by observations during excavations. Mound seems to have a complicated history of construction, with different phases in period between dates. Latter date represents the great mound after completion and before it was broken and robbed.

Structures connected with reindeer trapping in the Rondane area

\section{Einsethö series}

A hunting construction for trapping wild reindeer was discovered at +1100 to $1200 \mathrm{~m}$ at Einsethö, Dovre $\left(62^{\circ} 01^{\prime}\right.$ to $62^{\circ} 02^{\prime} \mathrm{N} \mathrm{Lat,} 9^{\circ} 27^{\prime}$ 
to $9^{\circ} 28^{\prime}$ E Long), Oppland, Norway, by E. K. Barth, Zool. Mus., Univ. Oslo. Small assemblages of stones id. as supporting stones for post holes in V-shaped fence system over $2900 \mathrm{~m}$ distance. Some remnants of wooden poles (all pine) were found from fence line, crossing brooks and peat bogs. Remnants of several house foundations were found ca. $100 \mathrm{~m}$ from tapering end of construction. Subm. 1969 to 1970 by E. K. Barth.

\section{T-1046. Einsethö, wood}

$910 \pm 90$

Remnants of pole below one of stones on top of a post hole (ca. No. 800). Coll. 1969 by E. K. Barth. Comment (E.K.B.): though pole was lying partly exposed (dry), a large part was preserved.

\section{T-795. Einsethö, wood}

$\mathbf{8 4 0} \pm 50$

Remnant from lower part of pole from peat bog (ca. No. 627). Coll. 1968 by E. K. Barth. Comment (E.K.B.): a depression at every 3rd $\mathrm{m}$ in bog indicated a pole.

\section{T-883. Einsethö, wood}

$1000 \pm 60$

Remnants of pole from a brook (ca. No. 96). Coll. 1969 by E. K. Barth. Comment (E.K.B.): pole was very well preserved and had almost the consistency of fresh wood.

\section{T-882. Einsethö, wood}

$760 \pm 60$

Remnant of pole in peat bog along same brook as for T-883 (ca. No. 90). Coll. 1969 by E. K. Barth. Comment (E.K.B.): pole was 0.92 $\mathrm{m}$ long, and largest of "ordinary poles."

\section{T-1045. Einsethö, wood}

$$
930 \pm 90
$$

Part of very large pole, $17 \mathrm{~kg}$, dry, from base of another brook. Coll. 1970 by E. K. Barth. Comment (E.K.B.): pole also belonged to fence system.

\section{T-884. Einsethö, charcoal}

$1380 \pm 80$

From cultural layer inside a house construction, at depth $0.28 \mathrm{~m}$. Coll. 1968 by E. K. Barth.

\section{T-1007. Einsethö, charcoal}

From cultural layer inside another house construction, at depth 0.05 to $0.12 \mathrm{~m}$. Coll. 1970 by A. Skjölsvold.

\section{T-915A. Einsethö, wood}

$$
1250 \pm 120
$$

Small pieces of wood from depth $0.45 \mathrm{~m}$ in refuse heap outside house. Coll. 1968 by E. K. Barth. 
T-915B. Einsethö, bone

A.D. 1150

$800 \pm 80$

Protein fraction of reindeer bones found in above mentioned refuse heap close to T-915A. Lab. Comment: protein fraction separated by dissolving sample $(50 \% \mathrm{HCl})$ and evaporating to dryness.

\section{T-715. Svartdalen, Lesja}

$1230 \pm 80$

Wood from wall in pit fall at $+1000 \mathrm{~m}$ in Svartdalen, Lesja $\left(62^{\circ}\right.$ $15^{\prime} \mathrm{N}$ Lat, $8^{\circ} 50^{\prime} \mathrm{E}$ Long), Oppland, Norway. In a series of 25 pits with stone walls, one had walls of split pine logs. Coll. 1967 by Ö Mölmen, Lesja; subm. 1968 by Tore Fossum, Norwegian Mus. Forestry, Elverum.

\section{T-885. Bråkdalshö, Sel}

$670 \pm 60$

Wood from vertical pole in center of pit fall at $+1440 \mathrm{~m}$ at Indre Bråkdalshö, Sel (61 ${ }^{\circ} 54^{\prime} \mathrm{N}$ Lat, $9^{\circ} 38^{\prime} \mathrm{E}$ Long), Oppland, Norway. Coll. and subm. 1969 by E. K. Barth. Comment (E.K.B.): hypothesis: pole used for spitting the animal.

\section{Spranget series}

A system of 42 pit falls at $+1050 \mathrm{~m}$ at Spranget, Sel $\left(61^{\circ} 50^{\prime} \mathrm{N}\right.$ Lat, $9^{\circ} 43^{\prime}$ to $9^{\circ} 44^{\prime}$ E Long), Oppland, Norway. Samples coll. and subm. 1969 to 1970 by E. K. Barth.

\section{T.916. Spranget $I$, wood}

$2050 \pm 70$

From depth $0.4 \mathrm{~m}$ below basal surface of $1 \mathrm{~m}$ leep pit, No. 33 . Comment (E.K.B.): possibly remnants from a covering frame $N$ top of pit.

\section{T-1028. Spranget II, charcoal}

From a layer $0.3 \mathrm{~m}$ below basal surface of a $1 \mathrm{~m}$ deep pit, No. 4 .

\section{Dovre series}

Wood remnants, from covering frame work in pit falis at +1250 $\mathrm{m}$ on Gravhö (ca. 62 $03^{\circ} \mathrm{N}$ Lat, $9^{\circ} 38^{\prime} \mathrm{E}$ Long), and at $+1300 \mathrm{~m}, 600$ m SW of Hornsjö $\left(62^{\circ} 02^{\prime} \mathrm{N}\right.$ Lat, $9^{\circ} 34^{\prime}$ E Long), respectively, Oppland, Norway. Subm. 1970 by E. K. Barth.

\section{T-1006. Dovre I, Gravhö}

Wood from depth $0.2 \mathrm{~m}$ below basal surface of $1.9 \mathrm{~m}$ deep pit. Coll. 1970 by E. K. Barth.

\section{T-1008. Dovre II, Gravhö}

$$
640 \pm 60
$$

Wooden sticks from depth 0.10 to $0.15 \mathrm{~m}$ below basal surface of 2 m deep pit. Coll. 1970 by A. Engen. 


\section{T-1010. Dovre III, Hornsjö}

A.D. 1300

$$
650 \pm 80
$$

Wooden sticks from depth $0.55 \mathrm{~m}$ below basal surface of pit. Coll. 1970 by A. Engen. Comment (E.K.B.): in the 2 latter pit falls many sticks were found, the longest, $0.40 \mathrm{~m}$.

$$
220 \pm 120
$$

\section{T-1009. Gunstadseter}

A.D. 1730

Small piece of wood from depth 0.10 to $0.15 \mathrm{~m}$ below basal surface of $2 \mathrm{~m}$ deep pit fall at $+980 \mathrm{~m}$ at Gunstadseter, Stor-Elvdal $\left(61^{\circ} 00^{\prime}\right.$ $\mathrm{N}$ Lat, $10^{\circ} 11^{\prime} \mathrm{E}$ Long), Hedmark, Norway. It belongs to system of 10 pits. Coll. 1970 by E. K. Barth. Comment (E.K.B.): may be last remnants of covering frame work.

\section{GEOCHEMICAL MEASUREMENTS}

\section{Modern shell series}

To evaluate recent $\mathrm{C}^{14}$ activity in marine shells formed on Norwegian coast line, 10 samples were measured. Samples were selected from colln. of Zool Mus., Bergen, by Johanne Kjennerud. Collection dates are precise and shells were alive at collection. Subm. 1970 by Jan Mangerud, Inst. Geology, Univ. Bergen.

General Comment: $\delta \mathrm{C}^{13}$ values quoted are relative to the $\mathrm{PDB}$ standard. Sample activities are corrected for age to the collection year and to $\delta \mathrm{C}^{13}=0 \%$. Values corresponding to $\delta \mathrm{C}^{13}=-25 \%$ are also given. The mean $\Delta$ value for samples is $-4 \pm 3 \%$. There is no signficant deviation between the $\mathrm{C}^{14}$ activity in the 10 recent shells and $95 \%$ of the activity in NBS oxalic acid. According to these measurements, variations in the apparent age of Norwegian coastal water is small, ranging from $340 \pm 75$ yr to $550 \pm 85 \mathrm{yr}$, with a mean value of $450 \mathrm{yr}$; this should not be a source of serious error in dates from Norwegian coastal shells. But 10 samples are a rather scanty number for such a long coast, and further investigation is desirable for verification.

T.951. Sognefjord, Buccinum undatum $\Delta=+1 \pm 9 \%$

$$
\Delta\left(\text { corrected to } \delta \mathrm{C}^{13}=-25 \%\right)=-49 \pm 9 \%
$$

Apparent age of water: $400 \pm 75 \mathrm{yr}$

From depth 20 to $40 \mathrm{~m}$ in Sognefjord at Leikanger $\left(61^{\circ} 11^{\prime} \mathrm{N}\right.$ Lat, 6 48' E Long), Sogn og Fjordane. Coll. 1912.

\section{T-952. Sognefjord, Linia excavata $\quad \Delta=-8 \pm 9 \%$ $\delta G^{13}=+2.1 \%$ \\ $\Delta(-25 \%)=-57 \pm 9 \%$} App. age of water: $470 \pm 75 \mathrm{yr}$

From depth $300 \mathrm{~m}$ in Sognefjord at Vangsnes $\left(61^{\circ} 10^{\prime} \mathrm{N}\right.$ Lat, $6^{\circ}$ 39' E Long), Sogn og Fjordane. Coll. 1920. 


\section{T-953. F jaerlandsfjord, Chlamys septemradiatus}

$$
\begin{array}{r}
\Delta=-\mathbf{1 0} \pm \mathbf{1 0} \% \\
\delta C^{13}=+2.7 \%
\end{array}
$$

$\Delta(-25 \%)=-60 \pm 10 \%$

App. age of water: $500 \pm 80 \mathrm{yr}$

From depth 180 to $200 \mathrm{~m}$ in Fjaerlandsfjord $\left(61^{\circ} 13^{\prime} \mathrm{N}\right.$ Lat, $6^{\circ} 34^{\prime}$ E Long to $61^{\circ} 22^{\prime} \mathrm{N}$ Lat, $6^{\circ} 85^{\prime} \mathrm{E}$ Long), Sogn og Fjordane. Coll. 1909. Sample diluted, $67 \%$ sample.

T-954A. Herdla, Cyprina islandica (outer fraction, $50 \%$ )

$$
\begin{array}{r}
\Delta=+\mathbf{1} \pm \mathbf{9} \% \\
\delta C^{13}=+1.9 \% \\
\Delta(-25 \%)=-49 \pm 9 \%
\end{array}
$$

App. age of water: $400 \pm 75 \mathrm{yr}$

From depth $10 \mathrm{~m}$ in Ideosen, Herdla $\left(60^{\circ} 34^{\prime} \mathrm{N}\right.$ Lat, $5^{\circ} 0^{\prime} \mathrm{E}$ Long), Hordaland. Coll. 1923.

T-954B. Herdla, Cyprina islandica (inner fraction, $50 \%$ )

$$
\begin{array}{r}
\Delta=-\mathbf{4} \pm \mathbf{9} \% \\
\delta C^{13}=+2.2 \% \\
\Delta(-25 \%)=-54 \pm 9 \%
\end{array}
$$

App. age of water: $450 \pm 75 \mathrm{yr}$

\section{T-955. Hardangerfjord, Cyprina islandica}

$$
\Delta=-\mathbf{1 0} \pm \mathbf{9} \%
$$

$$
\delta C^{13}=+2.6 \%
$$

$\Delta(-25 \%)=-59 \pm 9 \%$

App. age of water: $490 \pm 75 \mathrm{yr}$

From depth 20 to $50 \mathrm{~m}$ in Hardangerfjord at Solesnes, Jondal $\left(60^{\circ}\right.$ $18^{\prime} \mathrm{N}$ Lat, 6 ${ }^{\circ} 17^{\prime} \mathrm{E}$ Long), Hordaland. Coll. 1908.

T-956. Mosterhavn, Tapes pullastra

$$
\begin{array}{r}
\Delta=+\mathbf{5} \pm \mathbf{1 1} \% \\
\delta C^{13}=-0.2 \% \\
\Delta(-25 \%)=-45 \pm 11 \% 0 \\
\text { App. age of water: } 370 \pm 90 \mathrm{yr}
\end{array}
$$

From depth $15 \mathrm{~m}$ in Mosterhavn $\left(59^{\circ} 42^{\prime} \mathrm{N}\right.$ Lat, $5^{\circ} 24^{\prime} \mathrm{E}$ Long), Hordaland. Coll. 1918. Sample diluted, $46 \%$ sample.

\section{T-957. North Sea, Modiolus modiolus}

$$
\begin{array}{r}
\Delta=-\mathbf{4} \pm \mathbf{9} \% \\
\delta C^{13}=+1.9 \% \\
\Delta(-25 \%)=-54 \pm 9 \%
\end{array}
$$

App. age of water: $450 \pm 75 \mathrm{yr}$

From depth 110 to $115 \mathrm{~m}$ in North Sea $\left(60^{\circ} 38^{\prime} \mathrm{N}\right.$ Lat, $2^{\circ} 35^{\prime} \mathrm{E}$ Long), approx. half way between Bergen in Norway and Shetland. Coll. 1906. Sample diluted, $88 \%$ sample.

\section{T-958. Komagfjord, Mytilus edulis}

$$
\begin{array}{r}
\Delta=-\mathbf{1 4} \pm \mathbf{9} \% \\
\delta C^{13}=0.0 \% \\
\Delta(-25 \%)=-63 \pm 9 \%
\end{array}
$$

App. age of water: $520 \pm 75 \mathrm{yr}$

From depth 0 to $10 \mathrm{~m}$ in Komagfjord $\left(70^{\circ} 16^{\prime} \mathrm{N}\right.$ Lat, $23^{\circ} 24^{\prime} \mathrm{E}$ Long), Finnmark. Coll. 1922. 


\section{T-959. Brevikfjord, Chlamys septemradiatus}

$$
\begin{array}{r}
\Delta=-\mathbf{1 6} \pm \mathbf{1 0} \% o \\
\delta C^{13}=+0.8 \% o \\
\Delta(-25 \% o)=-66 \pm 10 \% o
\end{array}
$$

App. age of water: $550 \pm 80 \mathrm{yr}$

From depth 100 to $120 \mathrm{~m}$ in Brevikfjord (59 $03^{\prime} \mathrm{N}$ Lat, $9^{\circ} 42^{\prime}$ E Long), Telemark. Coll. 1898. Sample diluted, 55\% sample.

\section{T-960. Risör, Modiolus modiolus}

$$
\begin{array}{r}
\Delta=+\mathbf{9} \pm \mathbf{9} \% \text { o } \\
\delta C^{13}=+1.4 \% o \\
\Delta(-25 \%)=-42 \pm 9 \% \text { o }
\end{array}
$$

App. age of water: $340 \pm 75 \mathrm{yr}$

From depth $10 \mathrm{~m}$ in Grönholmsund, Risör $\left(58^{\circ} 44^{\prime} \mathrm{N}\right.$ Lat, $9^{\circ} 18^{\prime}$ E Long), Aust-Agder. Coll. 1905.

\section{REFERENCES}

Andersen, B. G., 1954, Front and lateral moraines in southwestern Norway: Norsk geog. tidsskr. Bd. 14, p. 274-342.

1960, The late and postglacial history of southern Norway between Fevik and Ana-Sira: Norges geol. unders., no. 210, 142 p.

1964, Har Jaeren vaert dekket av en Skagerak-bre?: Norges geol. unders., no. 228 , p. $5-11$

Anundsen, K., 1968, Comments on stages of glacial retreat in southwestern Norway: Geol. Fören. Förh., v. 90, no. 543, p. 453.

Anundsen, K. and Simonsen, A., 1968, Et Pre-borealt breframstöt på Hardangervidda og i området mellom Bergensbanen og Jotunheimen: Univ. Bergen Årb., Mat.Naturvit. ser. 1967, no. 7, 42 p.

Barth, Edvard K., 1958, Reinsdyrgraver i Rondane: Den norske Turistforen. årb., p. 120-124.

1970, Gamle fangstanlegg for rein i Rondane: Den norske Turistforen. årb., p. 158-167.

Bergström, B., 1971, Deglasiasjonsforlöpet i Aurlandsdalen og områdene omkring: Doctoral thesis, Univ. Bergen (unpub.).

Danielsen, Anders, 1972, A pine forest of Boreal age in a clay slide at Ullevål Stadion, Oslo, Norway: Norwegian Jour. Botany, v. 19 (in prep.)

Espedal, Odd, 1966, Espeland: Frá haug og heidni, v. 6, no. 3, p. 237-241.

1967, Ei folkevandringstids grav fra Espeland i Höyland: Frá haug og heidni, v. 7 , no. 3 , p. 59-61

Hafsten, Ulf, 1956, Pollen-analytic investigations on the late Quaternary development in the inner Oslofjord area: Univ. Bergen årb. 1956, Nat. r. 8. 1960, Pollen-analytic investigations in South Norway, in: O. Holtedahl, Geology of Norway: Norges geol. unders., no. 208, pp. 434-462.

IIoltedahl, Olaf, 1928-29, Om landisens bortsmelting fra strökene ved Trondheimsfjorden: Norsk geog. tidsskr., v. 2, p. 95-118.

1953, Norges geologi v. 2: Norges geol. unders., no. 164, p. 734

Ingstad, A. S., 1971, The Norse Settlement at L'Anse aux Meadows, Newfoundland. A preliminary report from the excavations 1961-68: Acta Archaeologica, v. 41, 1970 , in press.

Ingstad, Helge, 1964, Vinland ruins prove Vikings found the New World: Natl. Geographis, p. 708-734.

__ 1970, Westward to Vinland: Cape, London and St. Martin, New York.

Johansen, A. B., 1969, Höyfjellsfunn ved Laerdalsvassdraget I: Olso/Bergen: Universitetsforlaget 1969. Bergen: Årbok for Univ. Bergen 1969, Hum. serie.

Klovning, I. and Hafsten, U., 1965, An carly post-glacial pollen profile from Flåmsdalen, a tributary valley to the Sognefjord, western Norway: Norsk geol. tidsskr. no. 45 , p. $333-338$.

L.appalainen, Eino, 1970, Über die spätquartäre Entwicklung der Flussufermoore MittelLapplands: Bulletin de la Commission Géologique de Finlande, no. 244, p. 1-79. 
Lillehammer, A., 1969, Skagen 3 og Stavanger i mellomalderen: Frá haug og heidni, v. 9 , no. 2 , p. $229-239$.

Mangerud, Jan, 1970a, Interglacial sediments at Fjösanger, near Bergen, with the first Eemian pollenspectra from Norway: Norsk geol. tidsskr., v. 50, p. 167-181. 1970b, Late Weichselian vegetation and Ice-Front oscillations in the Bergen District, western Norway: Norsk geog. tidsskr., v. 24, p. 121-148.

Martens, Irmelin, and Hagen, Anders, 1961, Arkeologiske undersökelser langs elv og vann: Norske oldfunn, ser. 10 , Oslo, 95 p.

Möllerop, Odmund, 1969, Bygravninger i Stavanger: Frá haug og heidni, v. 9, no. 2, p. 141-144.

Nydal, Reidar et al., 1964, Trondheim natural radiocarbon measurements IV: Radiocarbon, v. 6, p. $280-290$.

1970, Trondheim natural radiocarbon measurements V: Radiocarbon, v. 12 , p. $205-237$ Odner, Knut, 1965, Vivik ved Holmevatn på Haukelifjell: Viking XXIX, Oslo, p.
201-243.

Ording, A., 1933-35, Myrens nytte for vernskogens bevarelse og for våre saeterbruk: Medd. fra Det norske myrselskap, p. 96-101.

Oyen, P. A., 1905, Nygårdsprofilet på Karmöen: Christiania Vidensk. Selsk. forh. 8, $15 \mathrm{p}$.

2, no. 1915, Kvartaerstudier i Trondheimsfeltet III: Kgl. N. Vid. Selsk. Skr. Bd.

Rolfsen, Perry, 1966, Naust med keramikk som handelsvare fra eldre-jernalder: Fu haug og heidni, v. 6 , no. 2 , p. 207-214.

Ruuhijärvi, R., 1963, Zur Entwicklungsgeschichte der nordfinnischen Hochmoore: Bot. Fennicae Annales, v. 34, no. 2, 40 p.

Sandnes, J., 1965, Namdalens historie til år 1600: Namsos.

Simonsen, A., 1969, Palynologiske undersökelser ved nausttuftene på “Öyren”, Hå: Stavanger Mus. Årb. 1969, p. 39-49.

Simonsen, P., 1970, Fortidsminner nord for Polarsirkelen: Univ. forlaget, Oslo.

Sjövold, T., 1962, The Iron age settlement of Arctic Norway: Tromsö Mus. Skr. X, no. 1, 253 p., Tromsö/Oslo. Norw. Univ. Press.

Undås, I., 1934, Fra istiden i Tröndelag: Kgl. N. Vid. Selsk. Skr., no. 7, p. 1-64

Vorren, B., 1970, Jordbrukshistorie, vegetasjons- og klima- utvikling i Skage i Overhalla, Namdalen: Thesis Univ. Trondheim, unpub.

bruk 1971, Pollenanalysen, - en kilde til bosetningshistorien. Litt om jord(

orren, K. D., 1967, Evig tele i Norge: Ottar, no. 51, 24 p.

ms. in preparation. 